In cooperation with the

U.S. Army Garrison, Aberdeen Proving Ground

Environmental Conservation and Restoration Division

Aberdeen Proving Ground, Maryland

\title{
Temporal and Vertical Variation of Hydraulic Head in Aquifers in the Edgewood Area, Aberdeen Proving Ground, Maryland
}

Water-Resources Investigations Report 98-4047

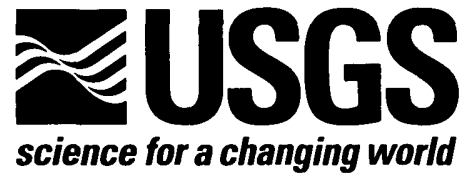




\section{Temporal and Vertical Variation of Hydraulic Head in Aquifers in the Edgewood Area, Aberdeen Proving Ground, Maryland}

by Colleen A. Donnelly and Frederick J. Tenbus

Water-Resources Investigations Report 98-4047

In cooperation with the

U.S. Army Garrison, Aberdeen Proving Ground

Environmental Conservation and Restoration Division

Aberdeen Proving Ground, Maryland

The contents of this report have been approved for public release and unlimited distribution by the U.S. Army -distribution number 2594-A-3. 
U.S. Department of the Interior

Bruce Babbitt, Secretary

U.S. Geological Survey

Thomas J. Casadevall, Acting Director

The use of trade, product, or firm names in this report is for descriptive purposes only and does not imply endorsement by the U.S. Geological Survey.

United States Government Printing Office: 1998

For additional information contact:

District Chief

U.S. Geological Survey, WRD

8987 Yellow Brick Road

Baltimore, MD 21237

Copies of this report can be purchased from:

U.S. Geological Survey

Branch of Information Services

Box 25286

Denver, CO 80225-0286 

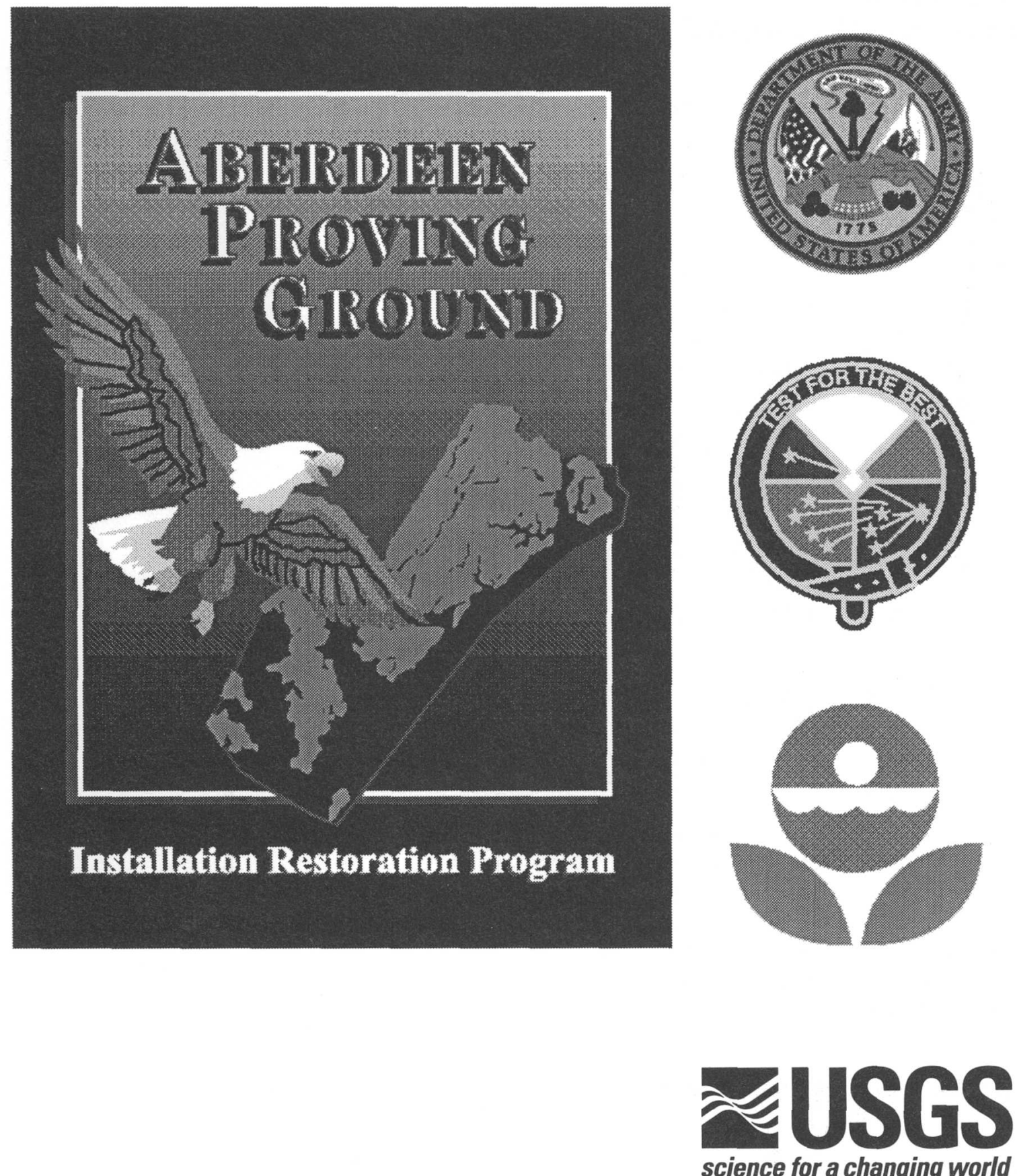

1998

Aberdeen Proving Ground, Edgewood Area 


\section{CONTENTS}

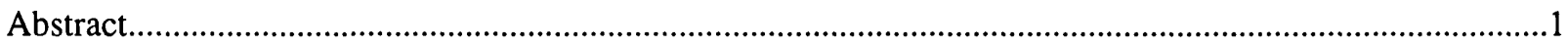

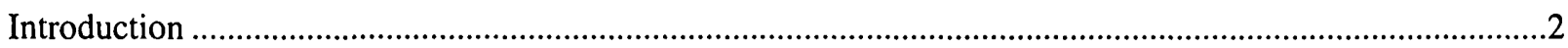

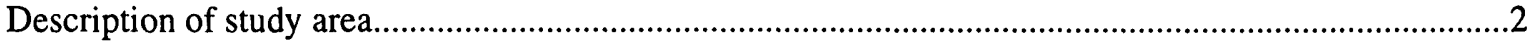

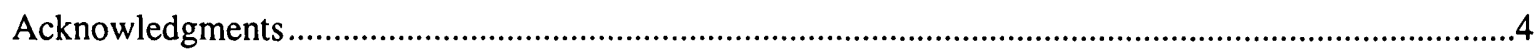

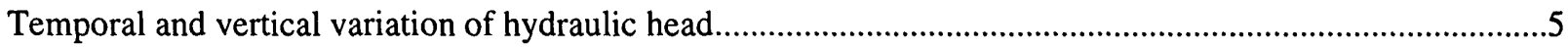

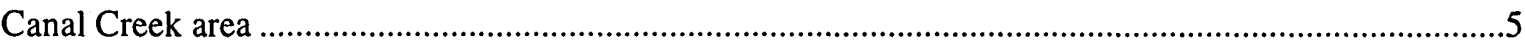

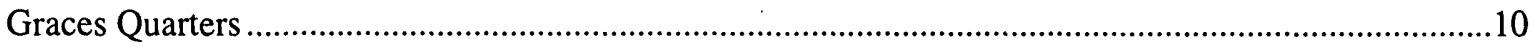

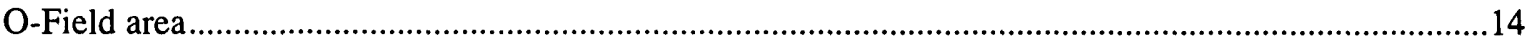

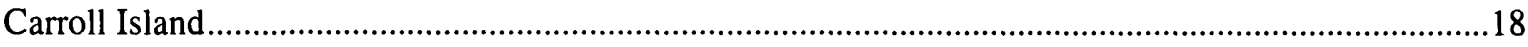

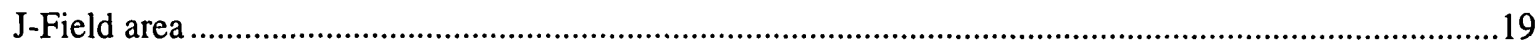

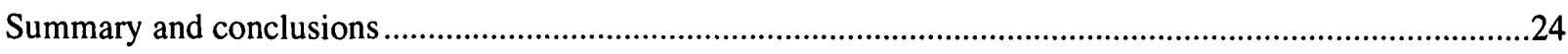

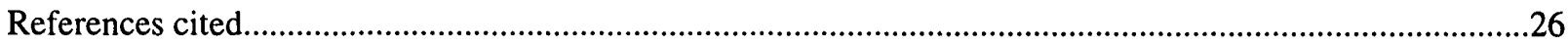

\section{FIGURES}

1. Map showing location of study sites in the Edgewood Area,

Aberdeen Proving Ground, Maryland ...............................................................................................

2. Schematic diagram showing geologic units and general ground-water-flow direction in the upper Chesapeake Bay area ..............................................................................

3. Cross section showing hydrogeologic units and general ground-water-flow direction in the Canal Creek area

4. Map showing selected wells, well clusters, and hydrographs of water levels in the Canal Creek area

5. Cross section showing hydrogeologic units and general ground-water-flow direction at Graces Quarters

6. Map showing selected wells, well clusters, and hydrographs of water levels at Graces Quarters

7. Cross section showing hydrogeologic units and general ground-water-flow direction in the O-Field area

8. Map showing selected wells, well clusters, and hydrographs of water levels in the O-Field area.

9. Cross section showing hydrogeologic units and general ground-water-flow direction on Carroll Island

10. Map showing selected wells, well clusters, and hydrographs of water levels on Carroll Island. 


\section{FIGURES--Continued}

11. Cross section showing hydrogeologic units and general ground-water-flow direction in the J-Field area

12. Map showing selected wells, well clusters, and hydrographs of water levels in the J-Field area

\section{TABLES}

1. Minimum and maximum vertical hydraulic gradients in selected well clusters in the

Canal Creek area

2. Minimum and maximum vertical hydraulic gradients in selected well clusters at

Graces Quarters

3. Minimum and maximum vertical hydraulic gradients in selected well clusters in the

O-Field area

4. Minimum and maximum vertical hydraulic gradients in selected well clusters on

Carroll Island.

5. Minimum and maximum vertical hydraulic gradients in selected well clusters in the

J-Field area

\section{CONVERSION FACTORS AND VERTICAL DATUM}

\begin{tabular}{llll}
\hline Multiply & By & To obtain \\
\hline inch (in.) & 2.54 & centimeter \\
foot (ft) & 0.3048 & meter \\
\hline
\end{tabular}

Sea Level: In this report, "sea level" refers to the National Geodetic Vertical Datum of 1929--a geodetic datum derived from a general adjustment of the first-order level nets of the United States and Canada, formerly called Sea Level Datum of 1929. 


\title{
TEMPORAL AND VERTICAL VARIATION OF HYDRAULIC HEAD IN AQUIFERS IN THE EDGEWOOD AREA,
} ABERDEEN PROVING GROUND, MARYLAND

By Colleen A. Donnelly and Frederick J. Tenbus

\begin{abstract}
Water-level data and interpretations from previous hydrogeological studies conducted by the U.S. Geological Survey in the Edgewood Area of Aberdeen Proving Ground (APG), Maryland, were compared to determine similarities and differences among the aquifers. Because the sediments that comprise the shallow aquifers are discontinuous, the shallow ground-water-flow systems are local rather than extensive across the Edgewood Area. Hydrogeologic cross sections, hydrographs of water levels, and vertical gradients calculated from previous studies in the Canal Creek area, Graces Quarters, the O-Field area, Carroll Island, and the J-Field area, over periods of record ranging from 1 to 10 years during 1986-97, were used to determine recharge and discharge areas, connections between aquifers, and hydrologic responses of aquifers to natural and anthropogenic stress. Each of the aquifers in the study areas exhibited variation of hydraulic head that was attributed to seasonal changes in recharge. Upward hydraulic gradients and seasonal reversals of vertical hydraulic gradients between aquifers indicate the potential for local groundwater discharge from most of the aquifers that were studied in the Edgewood Area. Hydraulic head in individual aquifers in Graces Quarters and Carroll Island responded to offsite pumping during part of the period of record. Hydraulic head in most of the confined aquifers responded to tidal loading effects from nearby estuaries.
\end{abstract}




\section{INTRODUCTION}

The Edgewood Area of Aberdeen Proving Ground (APG), Maryland (fig. 1), has been used to develop, test, and manufacture military-related chemicals since World War I. Military activity has contaminated the ground water in many parts of the Edgewood Area. The U.S. Geological Survey (USGS), in cooperation with the U.S. Army, has been conducting environmental studies in the Canal Creek area, Graces Quarters, the O-Field area, Carroll Island, and the J-Field area (fig. 1) since the mid-1980's. In addition, other agencies and private consulting firms have conducted studies at these and other sites within the Edgewood Area for a number of years.

The study areas are located on unconsolidated sand, silt, and clay deposits in the Atlantic Coastal Plain. These Coastal Plain sediments consist of the Patapsco Formation of the Potomac Group of Cretaceous age, which is an interbedded sand and clay unit of fluvial origin, and the Talbot Formation of Pleistocene age, which contains fluvial, estuarine, and marginal marine deposits comprising sand, gravel, and silty clay (Owens, 1969). The hydrogeologic units that comprise the shallow ground-water-flow systems within the Potomac Group and the Talbot Formation appear to be discontinuous and not extensive across the Edgewood Area.

This report describes aquifer characteristics such as recharge and discharge areas, connections between aquifers, and similarities in hydrologic responses of aquifers in different areas to natural and anthropogenic stress in the Edgewood Area of APG. Hydrogeologic cross sections, hydrographs of water levels, head differences, and vertical gradients were used to determine the similarities and differences among aquifers at five study sites in the Edgewood Area that are or were being studied in support of remedial investigations.
The primary sources of data for this study were reports from previous USGS studies and hydrographs and other water-level data collected by USGS that are on file at the Baltimore, Md. office of the USGS. Temporal variations of water levels in 19 wells from the Canal Creek area, Graces Quarters, the O-Field area, Carroll Island, and the J-Field area were used to illustrate how various aquifers are affected by seasonal recharge or by anthropogenic stresses such as pumping. Minimum and maximum vertical gradients were determined for 39 well pairs in the same study areas to determine areas of groundwater recharge or discharge. The period of record used for this study varied according to the available data. For most of the areas, the period of record was from 1 to 10 years during 1986-97.

\section{Description of Study Area}

The Edgewood Area of APG includes the Gunpowder Neck Peninsula in Harford County and Carroll Island and the Graces Quarters Peninsula in Baltimore County (fig. 1) and is located within the Atlantic Coastal Plain Physiographic Province. The Coastal Plain consists of unconsolidated deposits of sand, silt, and clay underlain by crystalline bedrock. These unconsolidated sediments dip gently to the east and southeast and form a wedge that originates at the Fall Line, where basement rock of the Piedmont Physiographic Province is exposed, and thickens to approximately $7,700 \mathrm{ft}$ at Ocean City, Md. (Vroblesky and Fleck, 1991). A diagram showing geologic units and general directions of ground-water flow in the upper Chesapeake Bay region is shown in figure 2. Climate in Maryland is generally temperate, with average annual precipitation of approximately 44 in. 


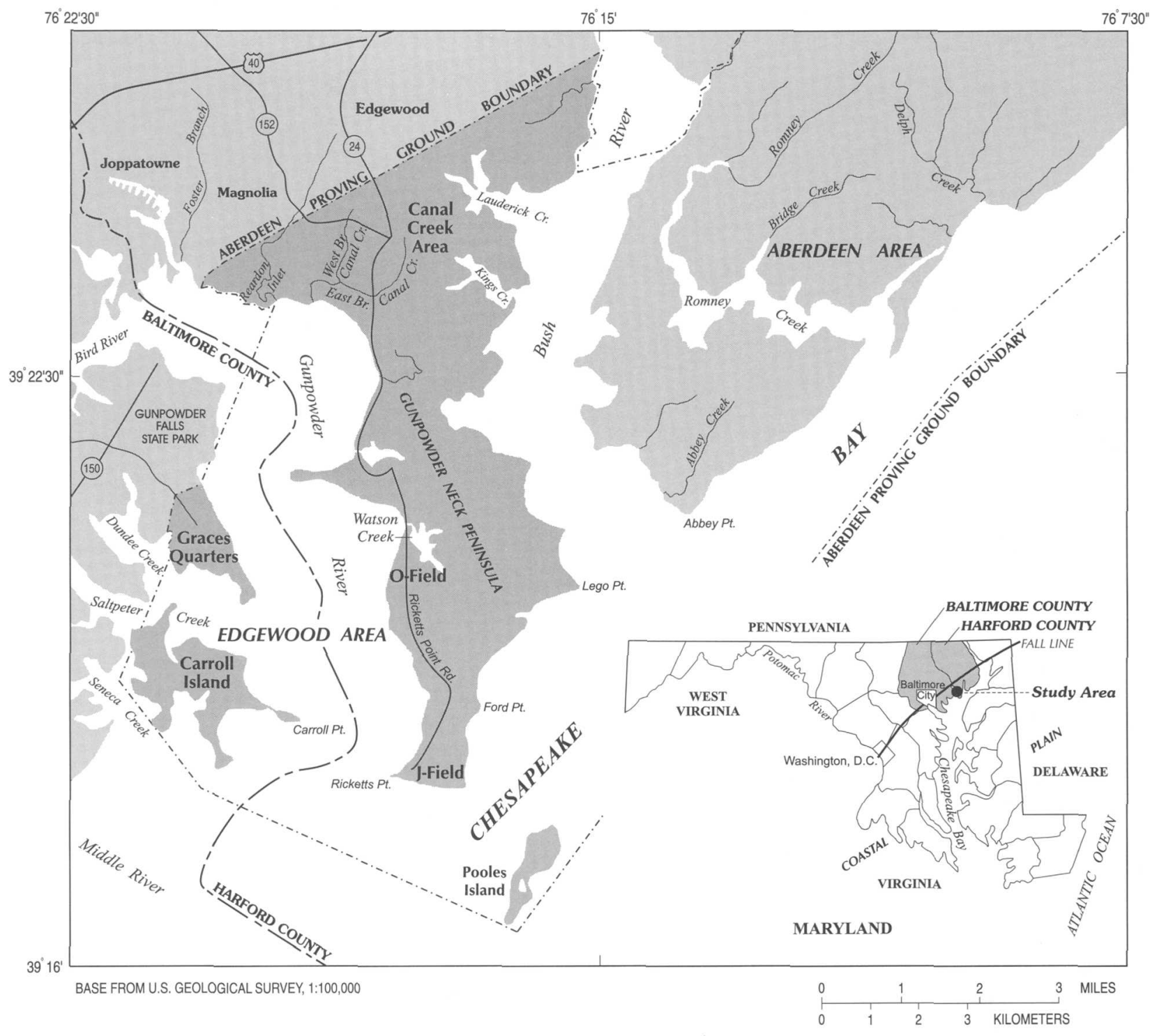

Figure 1. Location of study sites in the Edgewood Area, Aberdeen Proving Ground, Maryland. 


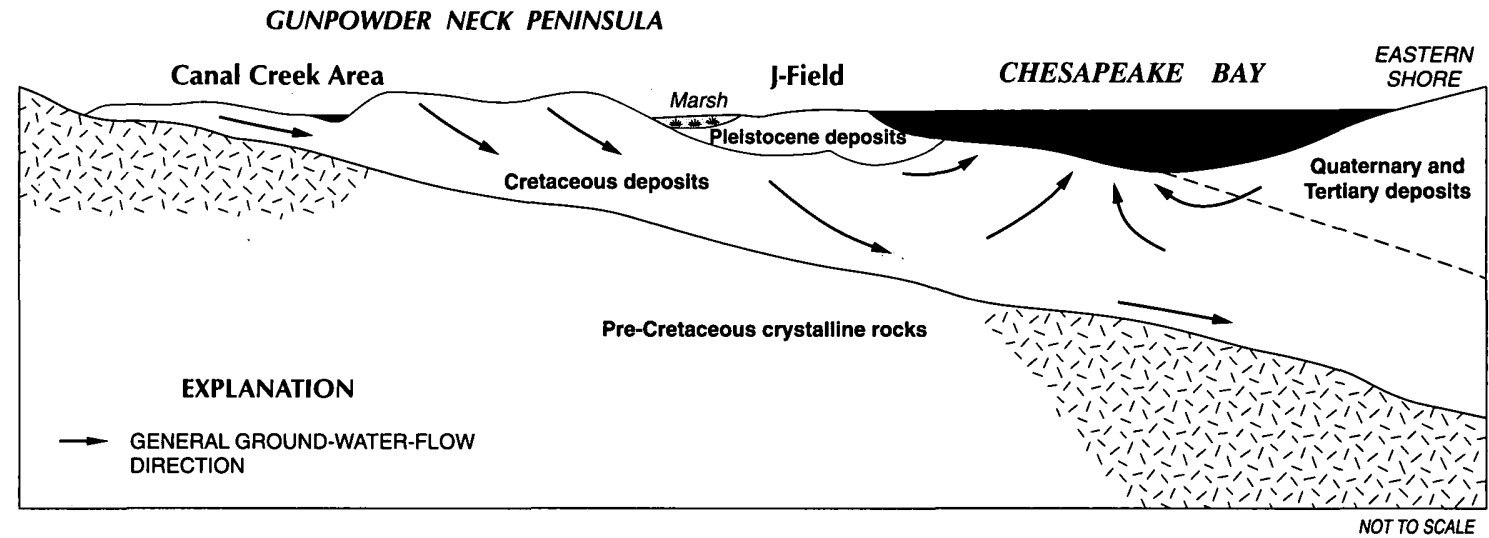

Figure 2. Geologic units and general ground-water-flow direction in the upper Chesapeake Bay area (modified from Hughes, 1993, p. 15).

USGS has conducted detailed hydrogeologic investigations at several areas within the Edgewood Area of APG--the Canal Creek area, Graces Quarters, the O-Field area, Carroll Island, and the J-Field area (fig. 1). The Canal Creek area is at the northern end of the Gunpowder Neck Peninsula. Surface-water bodies in the Canal Creek study area include Canal Creek and its East and West Branches, which flow into the Gunpowder River, and Lauderick Creek and Kings Creek, which flow into the Bush River. The O-Field area is approximately two-thirds of the way down the Gunpowder Neck Peninsula, south of the Canal Creek area. The O-Field area is bounded by Watson Creek on the north and east, and by the Gunpowder River on the west. The J-Field area is at the southern tip of the Gunpowder Neck Peninsula.

The other two study areas, Graces Quarters and Carroll Island, are within the Baltimore County part of APG, west of the Gunpowder River. Graces Quarters is a peninsula southeast of Gunpowder Falls State Park in eastern Baltimore County. This peninsula consists of wooded areas, open fields, low brush, and marshes, and is surrounded on three sides by estuaries--Gunpowder River to the northeast, Saltpeter Creek to the south, and Dundee Creek to the west. Carroll Island is just east of the Middle River area in eastern Baltimore County. This island consists of tidal marsh, open field, and wooded areas, and is surrounded by estuaries--Saltpeter Creek to the north, Gunpowder River to the east, Chesapeake Bay to the southeast, and Seneca Creek to the southwest. Seneca and Saltpeter Creeks separate Carroll Island from the mainland.

\section{Acknowledgments}

The authors wish to acknowledge the following people for their assistance on this project. Jerry Burgess of the Oak Ridge Institute for Science and Education (ORISE) and Paul Miller of the U.S. Army Corps of Engineers Waterways Experiment Station helped define the scope of the study and provided valuable technical discussion about the hydrogeology of Aberdeen Proving Ground. Elizabeth Marchand and Daniel Phelan of USGS helped to organize the available data for the project. Stephen Curtin, 
Charles Schalk, Dorothy Tepper, and Earl Greene from USGS provided technical reviews of this report.

\section{TEMPORAL AND VERTICAL VARIATION OF HYDRAULIC HEAD}

Hydrogeologic cross sections, hydrographs of water levels, and vertical gradients calculated from data collected during previous studies at the Canal Creek area, Graces Quarters, the O-Field area, Carroll Island, and the J-Field area in the Edgewood Area of APG were analyzed to determine aquifer characteristics such as recharge and discharge areas, connections between aquifers, and similarities in hydrologic responses of aquifers in different areas to natural and anthropogenic stress. Generalized hydrogeologic cross sections from previous studies are presented to provide the hydrogeologic framework within which to understand temporal and vertical variations of hydraulic head in the Edgewood Area. Hydrographs showing water levels from selected pairs of wells are used to illustrate diurnal and seasonal changes within an aquifer or between vertically adjacent aquifers. Minimum and maximum vertical gradients were calculated for selected pairs of wells to determine areas of ground-water recharge or discharge.

Water levels measured at well clusters throughout the Edgewood Area during previous studies were used to calculate vertical gradients. The difference in hydraulic head between selected pairs of wells, drilled very close to each other and screened at different depths, was determined from synoptic measurements of water levels collected over periods ranging from approximately 1 to 6 years. The difference in hydraulic head was then divided by the vertical distance between well screens in each pair of wells to compute the vertical gradient.

Wells in the Edgewood Area were leveled in with surveying equipment to an accuracy of at least a hundredth of a foot. Screen depths, and the resulting distances between adjacent screens, were measured to an accuracy of a tenth of a foot. Water levels were measured to an accuracy of a hundredth of a foot. The vertical gradients are calculated to a hundredth of a foot.

\section{Canal Creek Area}

Three aquifers--the surficial aquifer, the Canal Creek aquifer, and a lower confined aquifer--and their associated confining units were delineated by Oliveros and Vroblesky (1989) using a combination of hydrologic characteristics of the units and stratigraphic relations between the units. The surficial aquifer is in direct hydraulic connection with the underlying Canal Creek aquifer within a sand-filled paleochannel and near the West Branch of Canal Creek (fig. 3). These two aquifers are lithologically similar, so the distinction between them was made on the basis of hydrologic data that indicated a divergence in flow (Oliveros and Vroblesky, 1989, p. 11). The Canal Creek aquifer is the uppermost confined aquifer, but it crops out in some parts of the study area and is unconfined in parts of the paleochannel and where the confining unit is eroded and missing. The lower confined aquifer and lower confining unit are relatively continuous throughout the Canal Creek area.

A number of factors influence ground-water flow within and between the aquifers in the Canal Creek area. Ground-water flow in the surficial aquifer was described by Oliveros and Vroblesky (1989, p. 23-24) as dominated by a local flow system in which most recharge occurs at topographic highs and discharge occurs at topographic lows. Sources of recharge include infiltration from precipitation (primarily at topographic highs) or surface water, infiltration from leaky storm drains near the creeks at high tides, and leakage from the underlying Canal Creek aquifer in places where there is an upward head gradient. Discharge from the surficial aquifer travels directly to surface-water bodies, indirectly to surface-water bodies through leaky storm drains, and to the Canal Creek aquifer in areas of vertically downward head gradients.

Interpretations of hydrographs of water levels (fig. 4) and vertical gradients (table 1) in the Canal Creek area are consistent with the Oliveros and Vroblesky (1989) interpretations of the surficial aquifer hydrology. Seasonal variation is defined here as the approximate difference between the highest water level in the wet season 


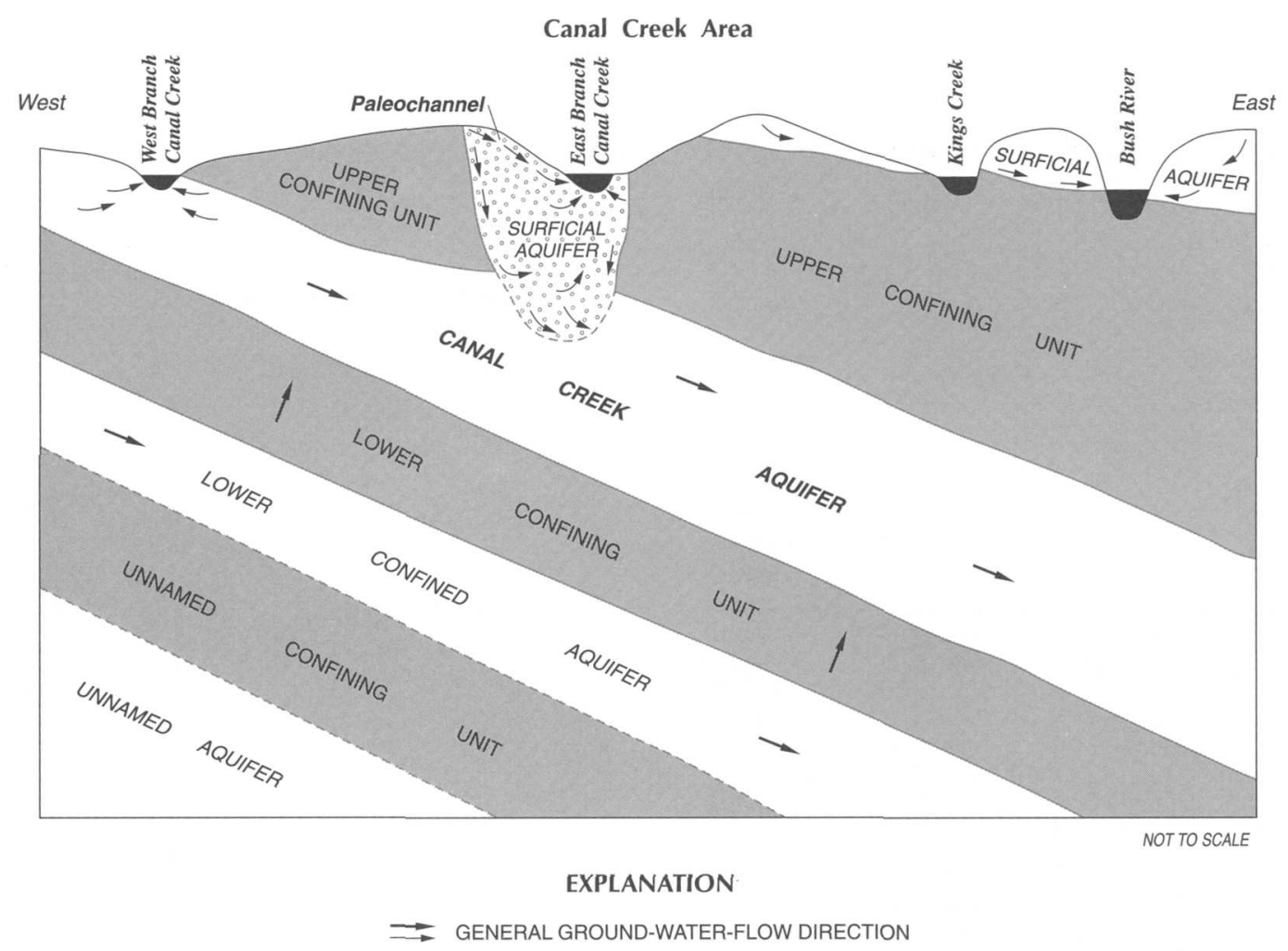

Figure 3. Hydrogeologic units and general ground-water-flow direction in the Canal Creek area, Aberdeen Proving Ground, Maryland (from Lorah and Clark, 1996, p. 11).

and the lowest water level in the dry season. The hydrograph of water levels at well CC-1A in the surficial aquifer exhibits a seasonal variation of about $3 \mathrm{ft}$, indicating that seasonal differences in precipitation and evapotranspiration have an effect on recharge to the surficial aquifer. Upward hydraulic gradients between the surficial and Canal Creek aquifers (table 1) indicate that the surficial aquifer is receiving recharge from the Canal Creek aquifer at well pairs CC-1A and -1B, and CC-20A and -20D, near East Branch Canal Creek. The downward head gradients at well pairs $\mathrm{CC}-5 \mathrm{~A}$ and $-5 \mathrm{~B}, \mathrm{CC}-9 \mathrm{~A}$ and $-9 \mathrm{~B}, \mathrm{CC}-23 \mathrm{~A}$ and $-23 \mathrm{~B}, \mathrm{CC}-36 \mathrm{~A}$ and $-36 \mathrm{D}$, and $\mathrm{CC}-124 \mathrm{~A}$ and $-124 \mathrm{~B}$, indicate discharge from the surficial aquifer to the Canal Creek aquifer. The cause of the variable gradient direction at well pair CC-22A and $-22 \mathrm{C}$ is not clear, because only one of nine water-level measurements at this well pair (Oliveros and Vroblesky, 1989, table 3; Lorah and Clark, 1996, app. A6) showed a downward hydraulic gradient. An upward gradient probably exists most of the time.
In the Canal Creek aquifer, ground-water flow has a local component near the West and East Branches of Canal Creek, and a more regional component in areas where the aquifer is not in direct hydraulic contact with surface water (Oliveros and Vroblesky, 1989, p. 35). The Canal Creek aquifer receives recharge as downward vertical flow from the surficial aquifer, upward vertical flow from the lower confined aquifer, and horizontal flow from the upgradient parts of the Canal Creek aquifer (Oliveros and Vroblesky, 1989, p. 35). Discharge is described as being either to the surficial aquifer near the West and East Branches of Canal Creek or to regional discharge areas offsite (Lorah and Clark, 1996, p. 15).

Hydrographs of water levels in wells completed in the Canal Creek aquifer (CC-1C, CC-8C, and CC-27A and -27B) indicate that 
Table 1. Minimum and maximum vertical hydraulic gradients in selected well clusters in the Canal Creek area, Aberdeen Proving Ground, Maryland

[Screen midpoint elevation in feet above or below sea level; vertical gradients in feet per foot; <, less than; --, no gradient of the specified direction was noted during the period of record; shading and white space used to delineate well pairs used to calculate vertical gradients]

\begin{tabular}{|c|c|c|c|c|c|c|c|}
\hline \multirow{3}{*}{$\begin{array}{l}\text { Well } \\
\text { no. } \\
\text { (fig. 4) }\end{array}$} & \multirow{3}{*}{$\begin{array}{l}\text { Aquifer } \\
\text { name }\end{array}$} & \multirow{3}{*}{$\begin{array}{l}\text { Aquifer } \\
\text { type }^{2}\end{array}$} & \multirow{3}{*}{$\begin{array}{l}\text { Screen } \\
\text { midpoint } \\
\text { elevation }\end{array}$} & \multicolumn{4}{|c|}{ Vertical gradient ${ }^{3}$} \\
\hline & & & & \multicolumn{2}{|c|}{ Upward } & \multicolumn{2}{|c|}{ Downward } \\
\hline & & & & Minimum & Maximum & Minimum & Maximum \\
\hline$\frac{9 C 1 A}{C \cdot 1 B}$ & Surficial & $\begin{array}{l}\text { Unconfined. } \\
\text { Unconfined. }\end{array}$ & 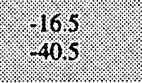 & 80.01 & : & & \\
\hline $\begin{array}{l}\text { CC-1C } \\
\text { CC-1D }\end{array}$ & $\begin{array}{l}\text { Canal Creek } \\
\text { Lower confined }\end{array}$ & $\begin{array}{l}\text { Unconfined } \\
\text { Confined }\end{array}$ & $\begin{array}{r}-61.5 \\
-143.5\end{array}$ & $<.01$ & .01 & -. & -- \\
\hline $\mathrm{CC}_{2 \mathrm{~A}} \mathrm{~B}$ & Ganal Creel & Connined & $\begin{array}{l}24.5 \\
1335\end{array}$ & 05 & .05 & & \\
\hline $\begin{array}{l}\text { CC-5A } \\
\text { CC-5B }\end{array}$ & $\begin{array}{l}\text { Surficial } \\
\text { Canal Creek }\end{array}$ & $\begin{array}{l}\text { Unconfined } \\
\text { Semiconfined }\end{array}$ & $\begin{array}{r}-0.5 \\
-39.5\end{array}$ & -. & - & 0.12 & 0.16 \\
\hline$\frac{\operatorname{Cc} 6 A}{\operatorname{ce}-6 C}$ & $\begin{array}{l}\text { Ganal Greel } \\
\text { lower confined }\end{array}$ & Confined & 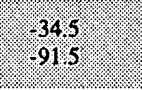 & $<01$ & 2001. & & \\
\hline $\begin{array}{l}\text { CC-9A } \\
\text { CC-9B }\end{array}$ & $\begin{array}{l}\text { Surficial } \\
\text { Canal Creek }\end{array}$ & $\begin{array}{l}\text { Unconfined } \\
\text { Confined }\end{array}$ & $\begin{array}{r}+9.5 \\
-100.5\end{array}$ & -. & -- & .08 & .08 \\
\hline$\frac{\operatorname{cec} 16 \AA}{\operatorname{ce} 160}$ & $\begin{array}{l}\text { Canal Greek } \\
\text { Lower confined }\end{array}$ & $\begin{array}{l}\text { Semiconfined } \\
\text { Confined: }\end{array}$ & -73.5 & 11 & 12 & & \\
\hline $\begin{array}{l}\mathrm{CC}-17 \mathrm{~A} \\
\mathrm{CC}-17 \mathrm{C}\end{array}$ & $\begin{array}{l}\text { Canal Creek } \\
\text { Lower confined }\end{array}$ & $\begin{array}{l}\text { Semiconfined } \\
\text { Confined }\end{array}$ & $\begin{array}{l}-11.5 \\
-90.5\end{array}$ & .09 & .10 & .. & -- \\
\hline $\begin{array}{l}\mathrm{CC} 20 \mathrm{~A} \\
\mathrm{CC}-20 \mathrm{D}\end{array}$ & Surficial & $\begin{array}{l}\text { Unconfined } \\
\text { Confined }\end{array}$ & $\begin{array}{r}-2.5 \\
59.5 \\
.9\end{array}$ & 01 & 03 & & \\
\hline $\begin{array}{l}\mathrm{CC}-22 \mathrm{~A} \\
\mathrm{CC}-22 \mathrm{C}\end{array}$ & $\begin{array}{l}\text { Surficial } \\
\text { Canal Creek }\end{array}$ & $\begin{array}{l}\text { Unconfined } \\
\text { Confined }\end{array}$ & $\begin{array}{l}-12.5 \\
-55.5\end{array}$ & .01 & .01 & 4.. & .01 \\
\hline$\frac{\operatorname{cc} 23 \mathrm{~A}}{\cos _{23 \mathrm{~B}}}$ & Surficial & $\begin{array}{l}\text { Unconfined } \\
\text { Unconfined }\end{array}$ & . +1.5 & & & 05 & 06 \\
\hline $\begin{array}{l}C C-26 A \\
C C-26 C\end{array}$ & $\begin{array}{l}\text { Canal Creek } \\
\text { Lower confined }\end{array}$ & $\begin{array}{l}\text { Unconfined } \\
\text { Confined }\end{array}$ & $\begin{array}{r}-4.5 \\
-132.5\end{array}$ & .02 & .03 & -. & -- \\
\hline$\frac{\cos 21 \mathrm{~A}}{\mathrm{co}}$ & $\begin{array}{l}\text { Canal Creek } \\
\text { Canal Greek. }\end{array}$ & $\begin{array}{l}\text { Unconfined } \\
\text { Unconfined }\end{array}$ & - 26.5 & 04 & .05 & \%. & \\
\hline $\begin{array}{l}\text { CC-28A } \\
\text { CC-28C }\end{array}$ & $\begin{array}{l}\text { Canal Creek } \\
\text { Lower confined }\end{array}$ & $\begin{array}{l}\text { Unconfined } \\
\text { Confined }\end{array}$ & $\begin{array}{r}-7.5 \\
-111.5\end{array}$ & .05 & .05 & -- & -. \\
\hline$\frac{\operatorname{ccc} 36 \mathrm{~A}}{\mathrm{CC} 36 \mathrm{D}}$ & Surficial li & $\begin{array}{l}\text { Unconfined } \\
\text { Semiconfined }\end{array}$ & $\begin{array}{l}+1.5 \\
76.5\end{array}$ & & . & .01 & 02. \\
\hline $\begin{array}{l}\text { CC-123A } \\
\text { CC-123B }\end{array}$ & $\begin{array}{l}\text { Canal Creek } \\
\text { Canal Creek }\end{array}$ & $\begin{array}{l}\text { Confined } \\
\text { Confined }\end{array}$ & $\begin{array}{l}-51.5 \\
-75.5\end{array}$ & $<.01$ & .07 & -. & -. \\
\hline $\begin{array}{l}\operatorname{Cg} 124 \mathrm{~A} \\
\operatorname{Ce}-124 \mathrm{~B}\end{array}$ & Surricial & $\begin{array}{l}\text { Unconfined } \\
\text { Confined }\end{array}$ & . & & & 09. & \\
\hline
\end{tabular}

1 Based on data from Oliveros and Gernhardt (1989, table 1).

2 Based on data from Oliveros and Vroblesky (1989, figs. 6-11 and 17).

3 Based on data collected August 1988 through October 1989, Lorah and Clark (1996, Appendix A6).

${ }^{4}$ Only one gradient was calculated for the specified direction during the period of record. 

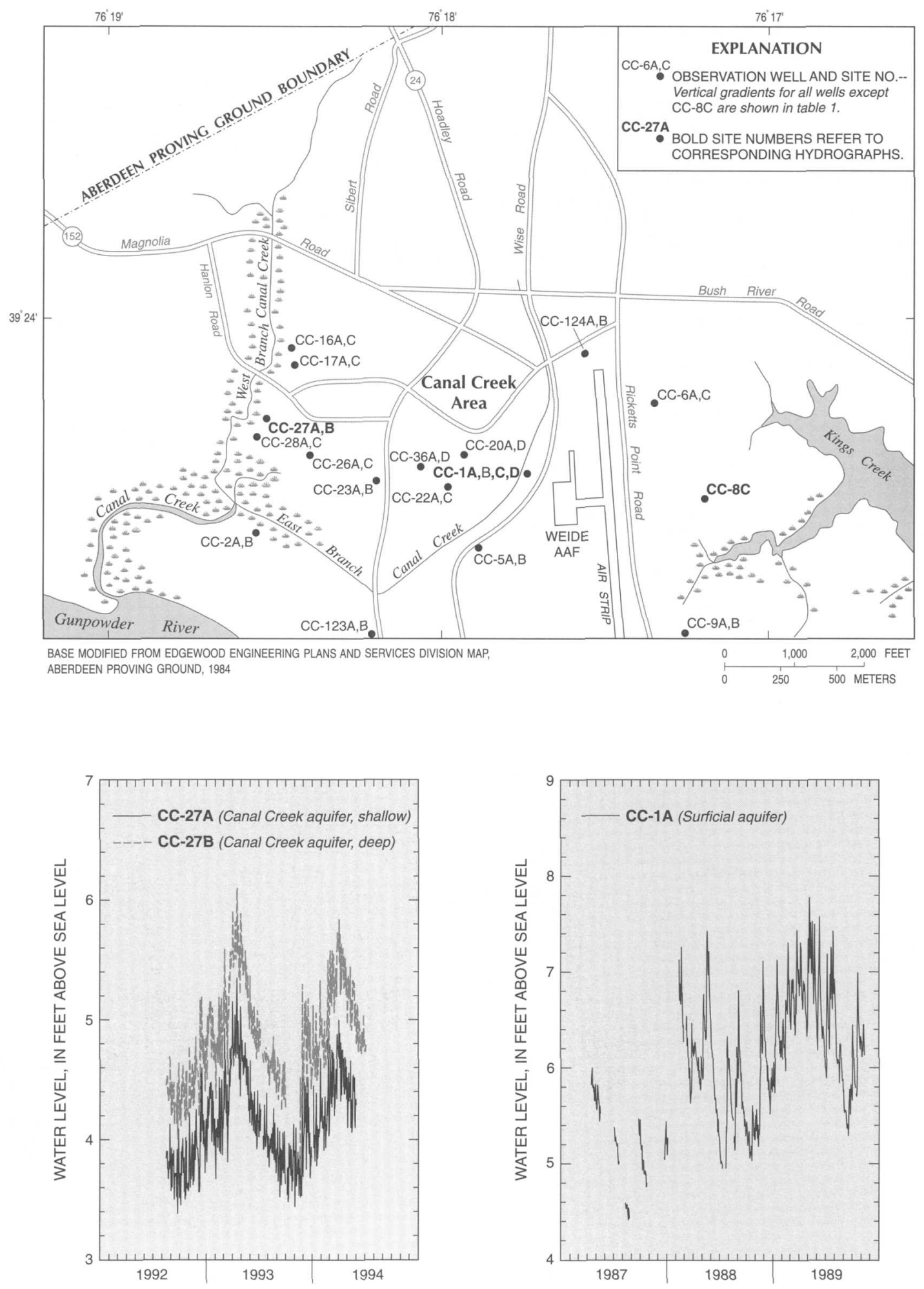

Figure 4. Selected wells, well clusters, and hydrographs of water levels in the Canal Creek area, Aberdeen Proving Ground, Maryland. 

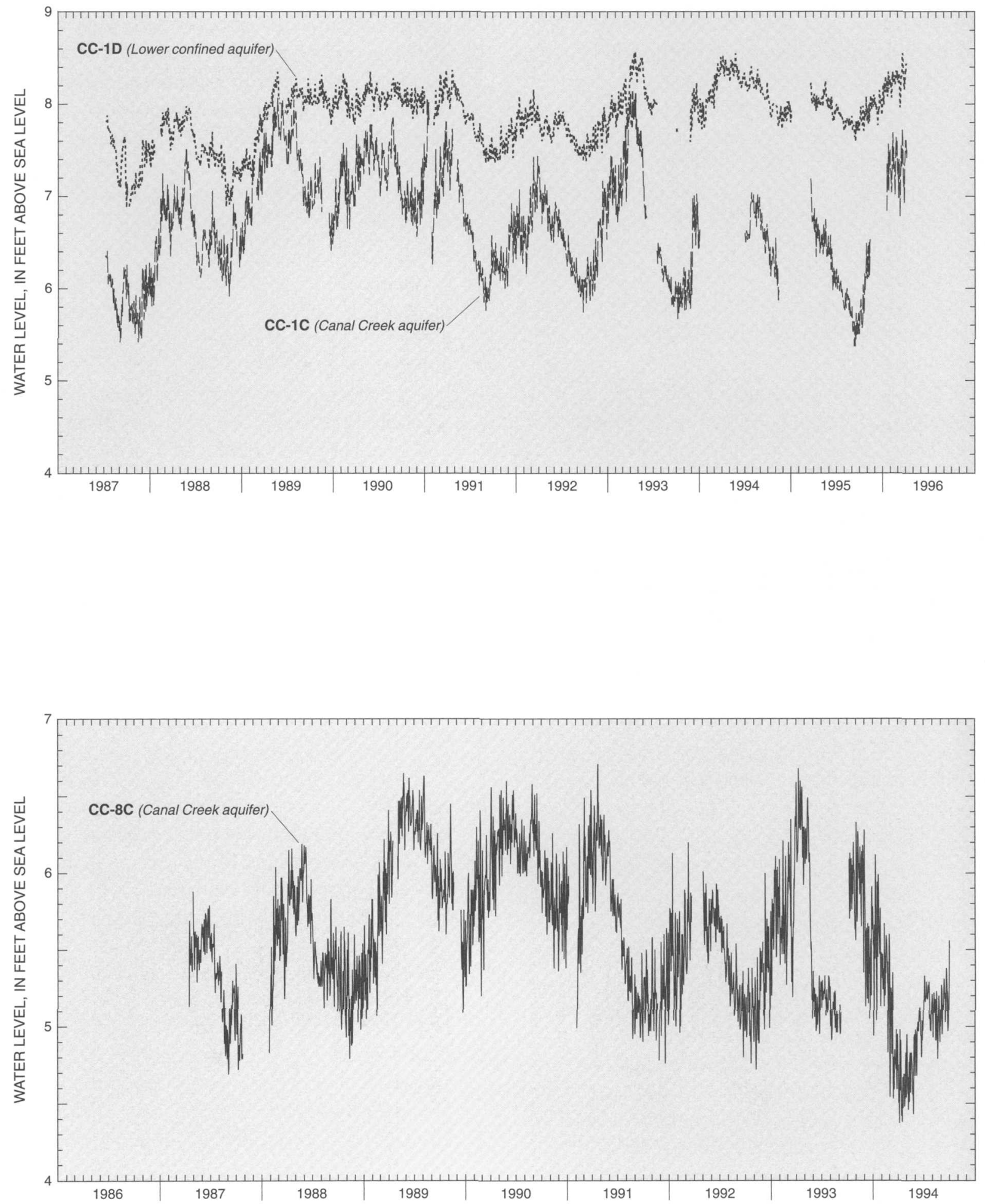

Figure 4. Selected wells, well clusters, and hydrographs of water levels in the Canal Creek area, Aberdeen Proving Ground, Maryland--Continued 
seasonal recharge to this aquifer occurs to varying degrees within the Canal Creek study area. Well CC-1C, which is within the paleochannel near East Branch Canal Creek, exhibits a seasonal head variation of about $2.5 \mathrm{ft}$ (fig. 4), indicating good hydraulic connection with the surface. The heads in wells CC-27A and -27B near West Branch Canal Creek also vary seasonally by about $2 \mathrm{ft}$, as does the head in well CC-8C (fig. 4), which is downdip in the Canal Creek aquifer, and is somewhat more isolated from the surface than other regions of this aquifer. This indicates that a seasonal variation in head may occur throughout the Canal Creek aquifer.

Upward hydraulic gradients at wells CC-1A and $-1 \mathrm{~B}$, and CC-20A and -20D (table 1) indicate local discharge zones near East Branch Canal Creek. An upward hydraulic gradient within the Canal Creek aquifer between wells CC-123A and CC-123B (table 1) indicates probable discharge from the aquifer into the Gunpowder River. West Branch Canal Creek is described in Lorah and others (1997, p. 31-37) as a discharge area for the Canal Creek aquifer; this is supported by the upward hydraulic gradient in wells CC-27A and -27B (table 1). Downward hydraulic gradients between the surficial and Canal Creek aquifers at the sites discussed earlier indicate that the Canal Creek aquifer obtains recharge from the surficial aquifer at some locations within the Canal Creek study area.

Between the shallow and deep parts of the Canal Creek aquifer in wells CC-27A and -27B, where the upper confining unit is absent, the magnitude of the minimum and maximum gradients is similar, indicating that seasonal variation does not affect head gradients between them. By contrast, in well $\mathrm{CC}-123 \mathrm{~A}$ and $-123 \mathrm{~B}$, where the upper confining unit is present, the maximum gradient (.07) indicating flow from the deep to the shallow part of the Canal Creek aquifer is an order of magnitude greater than the minimum head gradient $(<.01)$ at that well (table 1), indicating that seasonal variations of recharge affect the gradients in that area.

Little is known about ground-water flow in the lower confined aquifer because the lithology of this aquifer is complex (Oliveros and Vroblesky, 1989, p. 39). Horizontal ground-water flow is approximately northwest to southeast (Oliveros and
Vroblesky, 1989, p. 43); recharge to the aquifer is presumably upgradient of the study area, and discharge from the aquifer is likely to be beyond the Canal Creek area in the downgradient direction. Within the study area, the hydraulic head in the lower confined aquifer is higher than in the Canal Creek aquifer, and has been measured to be higher than land surface during the spring rainy season (Oliveros and Vroblesky, 1989, p. 43).

One hydrograph from the lower confined aquifer (for well CC-1D) is available (fig. 4). Seasonal recharge variation of about 1 foot is apparent from the hydrograph, indicating some hydraulic connection with the surface. Gradients between well pairs screened in the Canal Creek and lower confined aquifers are uniformly upward, although very slight in some locations (table 1). The upward gradients indicate the potential for local discharge from the lower confined aquifer. Upward hydraulic gradients near West Branch Canal Creek at wells CC-16A and $-16 \mathrm{C}$, and $\mathrm{CC}-17 \mathrm{~A}$ and $-17 \mathrm{C}$ were two orders of magnitude greater than the very slight upward gradient between wells CC-6A and -6C near Kings Creek to the east (table 1).

\section{Graces Quarters}

Aquifers and confining units that have been defined at Graces Quarters include the surficial aquifer, upper confining unit, middle aquifer, middle confining unit, lower aquifer, and lower confining unit (Tenbus and Fleck, 1996, table 1). The surficial and middle aquifers are not continuous over all of Graces Quarters (Tenbus and Fleck, 1996, table 1). The surficial aquifer generally is unconfined, is recharged by precipitation, and discharges to seeps and springs, tidal marshes, surrounding estuaries, and the deeper aquifers in areas where the upper confining unit is thin or nonexistent (Tenbus and Blomquist, 1995, p. 30). Discharge to the surrounding estuaries results in a predominantly southern and southeastern flow direction, although there is some local variation (Tenbus and Blomquist, 1995, p. 33-36; Tenbus and Fleck, 1996, p. 7, 8). The middle aquifer was described as a confined aquifer in Tenbus and Blomquist (1995) and Tenbus and Fleck (1996). Further 


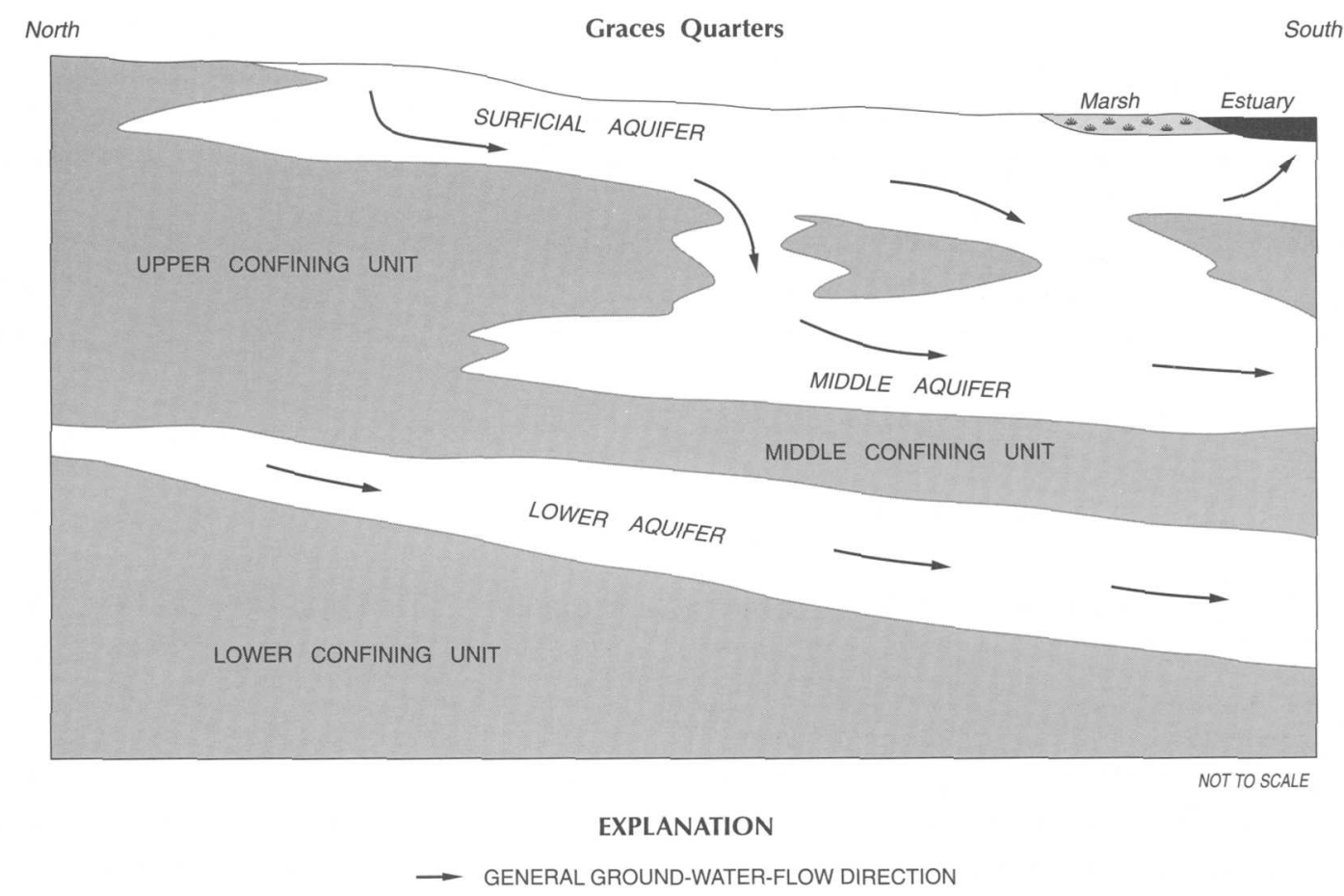

Figure 5. Hydrogeologic units and general ground-water-flow direction at Graces Quarters, Aberdeen Proving Ground, Maryland.

study indicated a high probability that the middle aquifer was semiconfined; this was confirmed during Remedial Investigation work at Graces Quarters (Scott Morgan and Timothy Llewellyn, Dames \& Moore, Inc., written commun., April 1997). The current (1998) conceptual model of the aquifers and confining units at Graces Quarters is shown in figure 5 .

Hydrographs of water levels for two well pairs (Q16B and A; Q20B and A), screened in the surficial and middle aquifers, and one well (Q19A), screened in the lower aquifer, are shown in figure 6. Seasonal variations of 6 to $10 \mathrm{ft}$ are apparent in the surficial aquifer; variations of about $3.5 \mathrm{ft}$ are typical for the middle aquifer, and variations of about 1 foot can be seen in the lower aquifer (fig. 6). Pumping at an unknown offsite location affected the head in well Q19A in the lower aquifer during 1988-89, but these pumping effects were not apparent in any of the wells screened in the surficial or middle aquifers or at any of the other Edgewood study areas. Hydrographs of water levels in Ham and others (1991, figs. 13-23) showed that the hydraulic head in well Q19A dropped below sea level in June 1988 and remained at that level for several months into 1989, whereas the hydraulic head in other wells dropped at the same time but remained above sea level and recovered during the next wet season. Variations in recharge cause the higher hydraulic heads evident in the winter and early spring months, and the lower heads in the typically drier summer months for all three aquifers. The semiconfined nature of the middle aquifer is apparent in the seasonal head variations. This hydraulic connection is responsible for the similarity of the patterns of head rise and fall throughout the period of record for the well pairs. The presence of silt and clay confining units between the deep and shallow screens of the well pairs (Ham, Tenbus, and others, 1991, table 6) and proximity of the wells to tidal estuaries helps explain the short-term water-level fluctuations in the deep wells, which indicate tidal loadings on the middle and lower aquifers. 

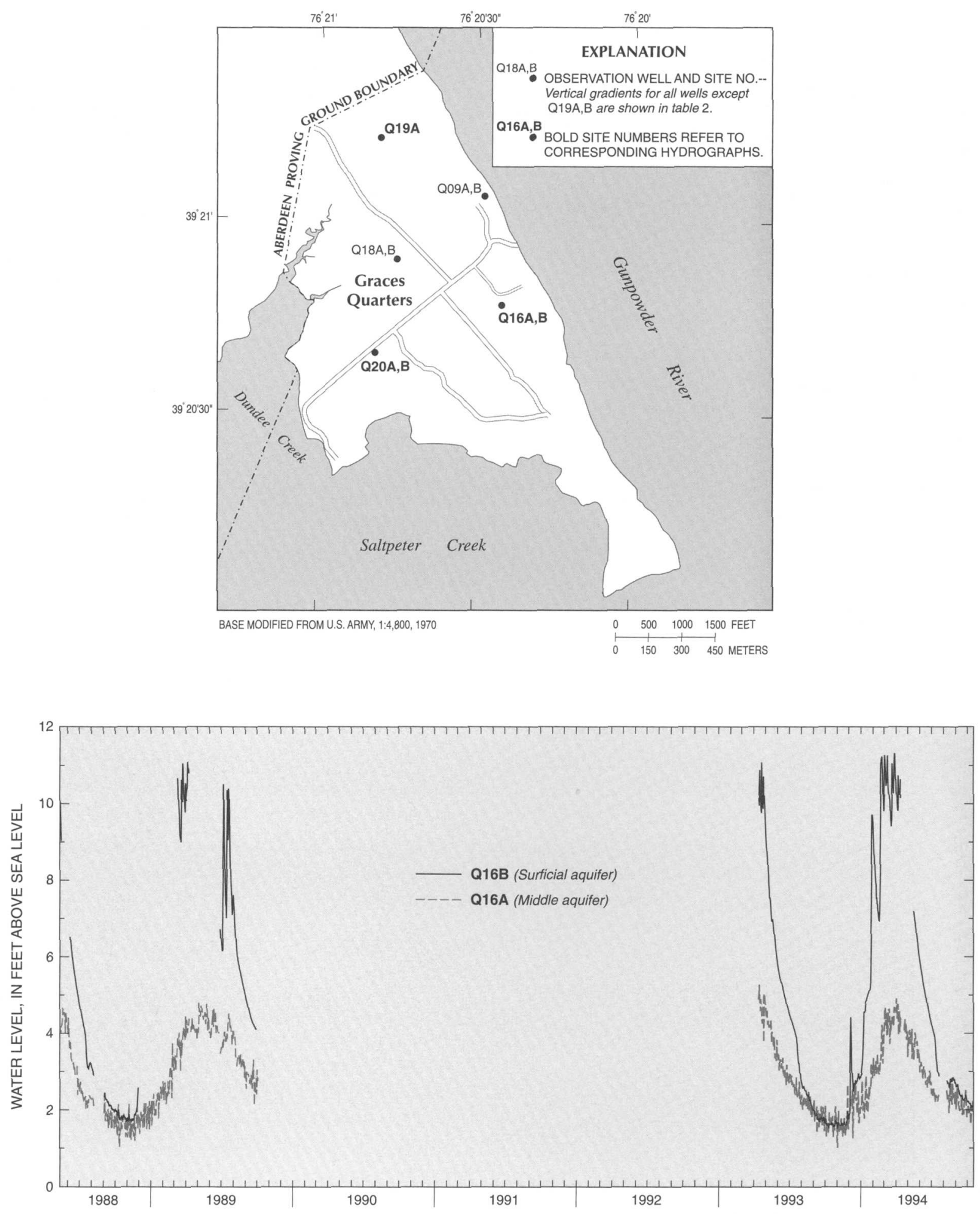

Figure 6. Selected wells, well clusters, and hydrographs of water levels at Graces Quarters, Aberdeen Proving Ground, Maryland. 

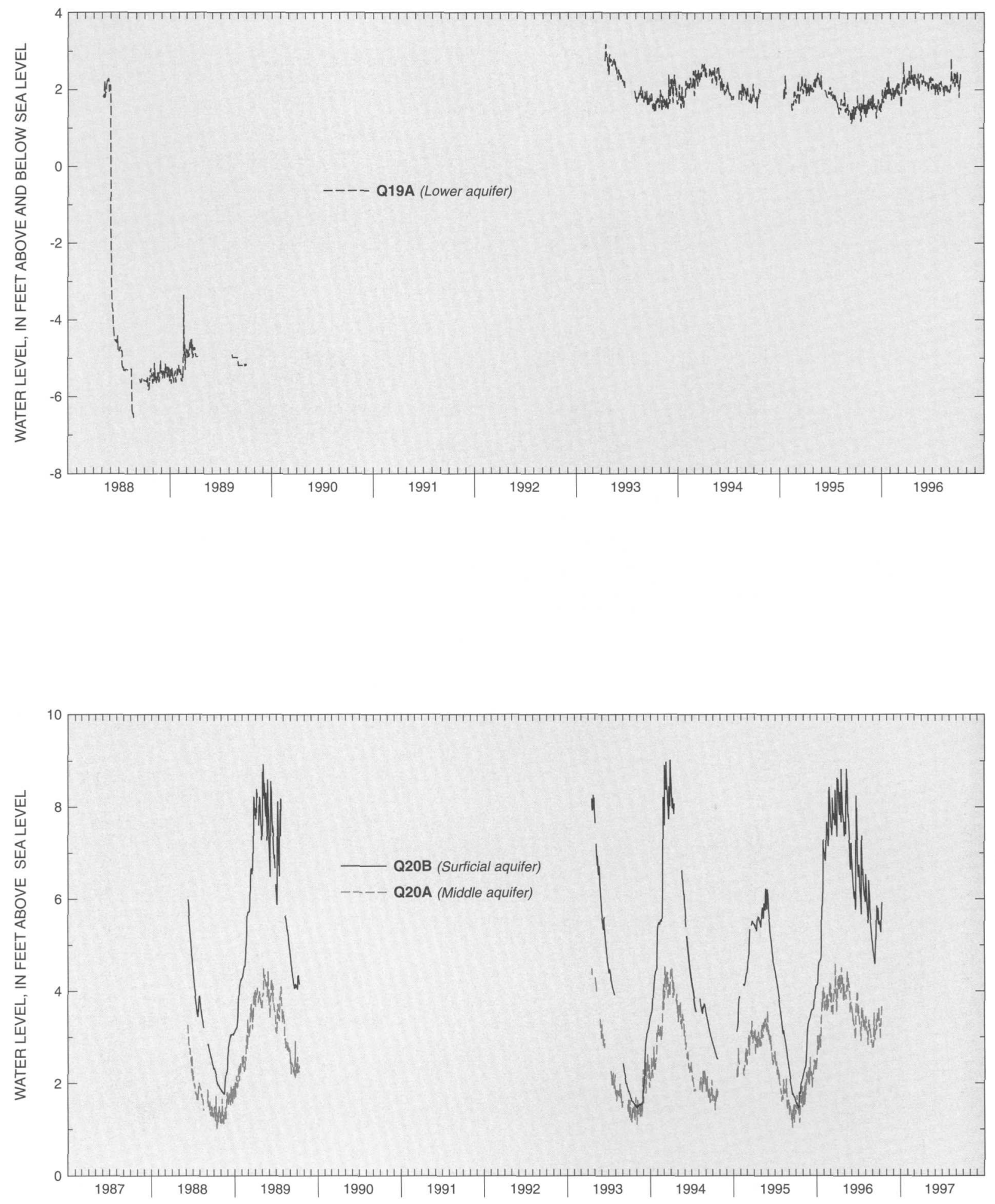

Figure 6. Selected wells, well clusters, and hydrographs of water levels at Graces Quarters, Aberdeen Proving Ground, Maryland---Continued 
Vertical gradients in well pairs at Graces Quarters are uniformly downward (table 2), in contrast to the spatially variable gradient directions evident in the Canal Creek area (table 1). Vertical gradients at wells $Q 16 B$ and $A$, Q18A and B, and Q20B and A (table 2) indicate that within the study area, the middle aquifer is recharged from the surficial aquifer. Higher recharge gradients generally occur in the spring and lower gradients are evident in the autumn and winter (Ham, Tenbus, and others, 1991, table 8). The uniformly downward hydraulic gradient may be an artifact of the locations of the well clusters in the USGS study. Water levels measured at Graces Quarters in August 1997 (Scott Morgan, written commun., 1997) indicate upward hydraulic gradients near the marshes and estuaries in at least five well pairs that did not exist at the time of the USGS study. Those upward hydraulic gradients between the middle and surficial aquifers demonstrate that the middle aquifer discharges to the surficial aquifer locally. The surficial aquifer then discharges to the estuaries surrounding Graces Quarters.
Vertical gradients between the surficial and lower aquifers (Q09A and B) are high compared to those at the other Graces Quarters wells and most of the wells in the Canal Creek area. The 100-ft-thick clay layer between the screened intervals at wells Q09A and B (Tenbus and Blomquist, 1995, fig. 11) indicates that the two aquifers are not hydraulically connected. The middle and lower aquifers do not appear to be hydraulically connected either.

\section{O-Field Area}

Three aquifers were defined by Vroblesky and others $(1995$, p. 11) in the first $120 \mathrm{ft}$ below land surface at the O-Field area--a water-table aquifer, the upper confined aquifer, and the lower confined aquifer (fig. 7). The water-table aquifer is typically about $10 \mathrm{ft}$ thick and is present throughout the study area. Recharge comes from precipitation, but may be somewhat retarded by the presence of clayey soil in some areas (Vroblesky and others, 1995, p. 13). In general, ground water flows radially away from the area south of O-Field and is discharged to Watson Creek and Gunpowder River (Banks and others, 1996, fig. 4).

Table 2. Minimum and maximum vertical hydraulic gradients in selected well clusters at Graces Quarters, Aberdeen Proving Ground, Maryland

[Screen midpoint elevation in feet above or below sea level; vertical gradients in feet per foot; <, less than; --, no gradient of the specified direction was noted during the period of record; shading and white space used to delineate well pairs used to calculate vertical gradients]

\begin{tabular}{|c|c|c|c|c|c|c|c|}
\hline \multirow{3}{*}{$\begin{array}{l}\text { Well no. } \\
\text { (fig. 6) }\end{array}$} & \multirow{3}{*}{$\begin{array}{l}\text { Aquifer } \\
\text { name }^{1}\end{array}$} & \multirow{3}{*}{$\begin{array}{l}\text { Aquifer } \\
\text { type }\end{array}$} & \multirow{3}{*}{$\begin{array}{l}\text { Screen midpoint } \\
\text { elevation }^{2}\end{array}$} & \multicolumn{4}{|c|}{ Vertical gradient $^{3}$} \\
\hline & & & & \multicolumn{2}{|c|}{ Upward } & \multicolumn{2}{|c|}{ Downward } \\
\hline & & & & Minimum & Maximum & Minimum & Maximum \\
\hline (009A & $\begin{array}{l}\text { Surficial } \\
\text { Lowert: }\end{array}$ & $\begin{array}{l}\text { Unconfined: } \\
\text { Confined: }\end{array}$ & $\begin{array}{c}+23.5 \\
109.0\end{array}$ & & 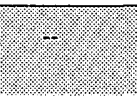 & 0.12 & (1: 0.26 \\
\hline $\begin{array}{l}\text { Q16B } \\
\text { Q16A }\end{array}$ & $\begin{array}{l}\text { Surficial } \\
\text { Middle }\end{array}$ & $\begin{array}{l}\text { Unconfined } \\
\text { Semiconfined }\end{array}$ & $\begin{array}{r}-.5 \\
-70.0\end{array}$ & -- & -- & $<.01$ & .10 \\
\hline $\begin{array}{l}018 \mathrm{~A} \\
018 \mathrm{~B}\end{array}$ & $\begin{array}{l}\text { Surficial. } \\
\text { Middle }\end{array}$ & $\begin{array}{l}\text { Unconfined: } \\
\text { Semiconfined }\end{array}$ & .7 .0 & & & .01 & 08 \\
\hline $\begin{array}{l}\text { Q20B } \\
\text { Q20A }\end{array}$ & $\begin{array}{l}\text { Surficial } \\
\text { Middle }\end{array}$ & $\begin{array}{l}\text { Unconfined } \\
\text { Semiconfined }\end{array}$ & $\begin{array}{r}+2.0 \\
-75.0\end{array}$ & -- & -- & .01 & .05 \\
\hline
\end{tabular}

${ }^{1}$ Nomenclature from Tenbus and Fleck (1996, table 1).

${ }^{2}$ Based on data from Ham, Tenbus, and others (1991, table 4).

3 Based on data collected February 1988 through March 1989, Ham, Tenbus, and others (1991, table 8). 


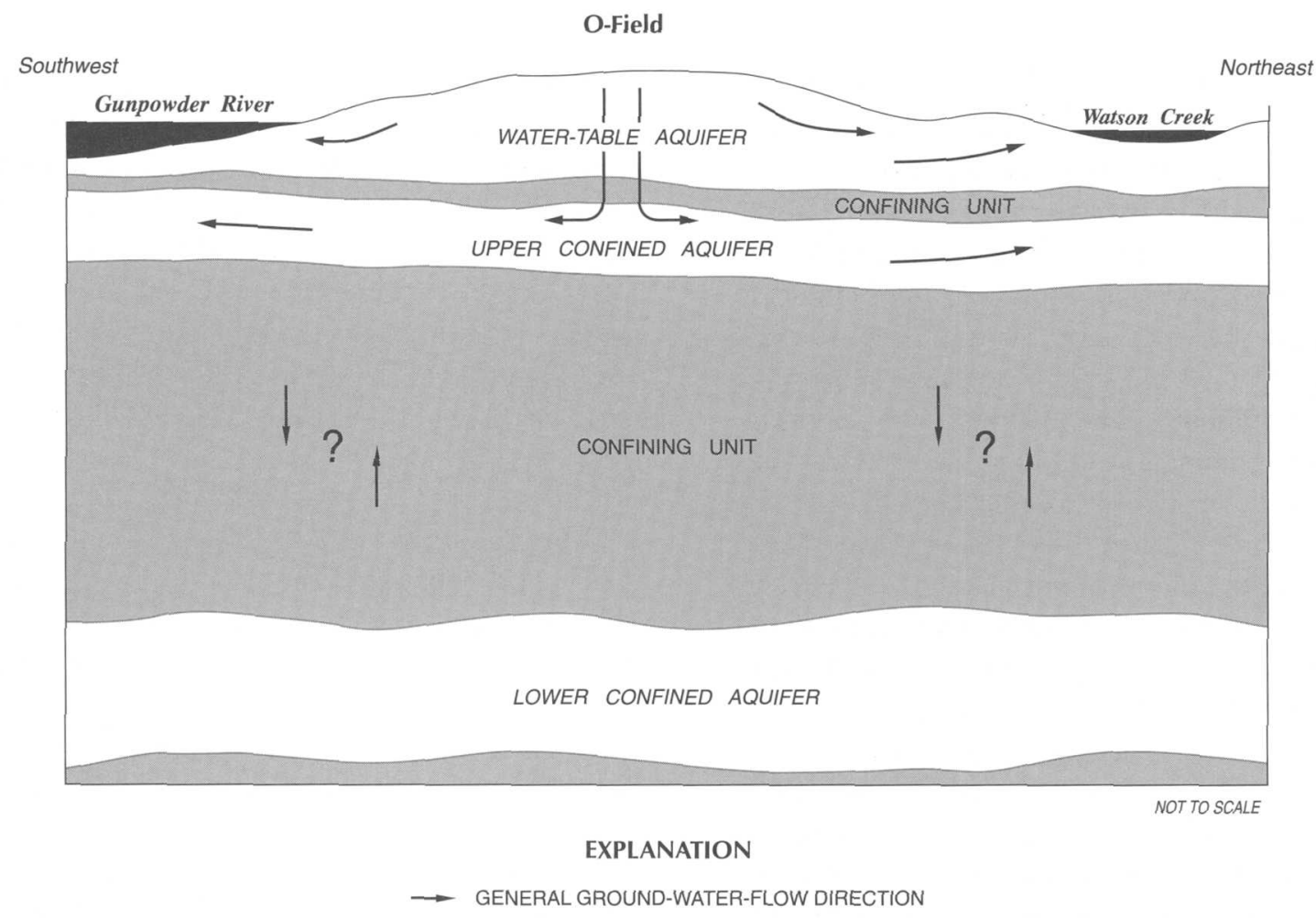

Figure 7. Hydrogeologic units and general ground-water-flow direction in the O-Field area, Aberdeen Proving Ground, Maryland.

The water-table aquifer is underlain by a thin ( 0.5 to $5 \mathrm{ft}$ ) upper confining unit of clay and, in the northeastern part of the area, clayey sand and silt (Vroblesky and others, 1995, p. 20). The presence of sandy materials in the confining unit in certain places, especially in the southern part of the study area (Vroblesky and others, 1995, p. 20; Banks and others, 1996, p. 9) indicates that vertical leakage between the water-table and upper confined aquifers is possible.

The upper confined aquifer is present throughout the O-Field area and ranges in thickness from about 1 to $14 \mathrm{ft}$ (Vroblesky and others, 1995, p. 21). Below the upper confined aquifer is another confining unit that appears to be continuous throughout the O-Field area (Vroblesky and others, 1995, p. 24). This confining unit is part of the Talbot Formation (Vroblesky and others, 1995, p. 11) and is similar to confining units found at Carroll Island and J-Field (Tenbus and Phillips, 1996, p. 33). The lower confined aquifer is approximately $20 \mathrm{ft}$ thick and the top of it is approximately $80 \mathrm{ft}$ below sea level (Vroblesky and others, 1995, p. 27).

Hydrographs of water levels for one well pair (OF16A and B) screened in the water-table and upper confined aquifers are shown in figure 8. Seasonal variations of recharge cause the higher hydraulic heads evident in the spring months, and the lower heads in the typically drier summer and autumn months. Seasonal reversals of hydraulic head between the water-table and upper confined aquifers in 1993-94 (fig. 8) indicate that the potential flow is upward from the upper confined aquifer toward the water-table aquifer during the dry season, and downward from the water-table aquifer toward the upper confined aquifer during the wet season. Vroblesky and others (1995, p. 23) indicate that the hydraulic head in the upper confined aquifer responds to tidal changes in Watson Creek, which indicates that the overlying confining unit is continuous beneath the creek. 

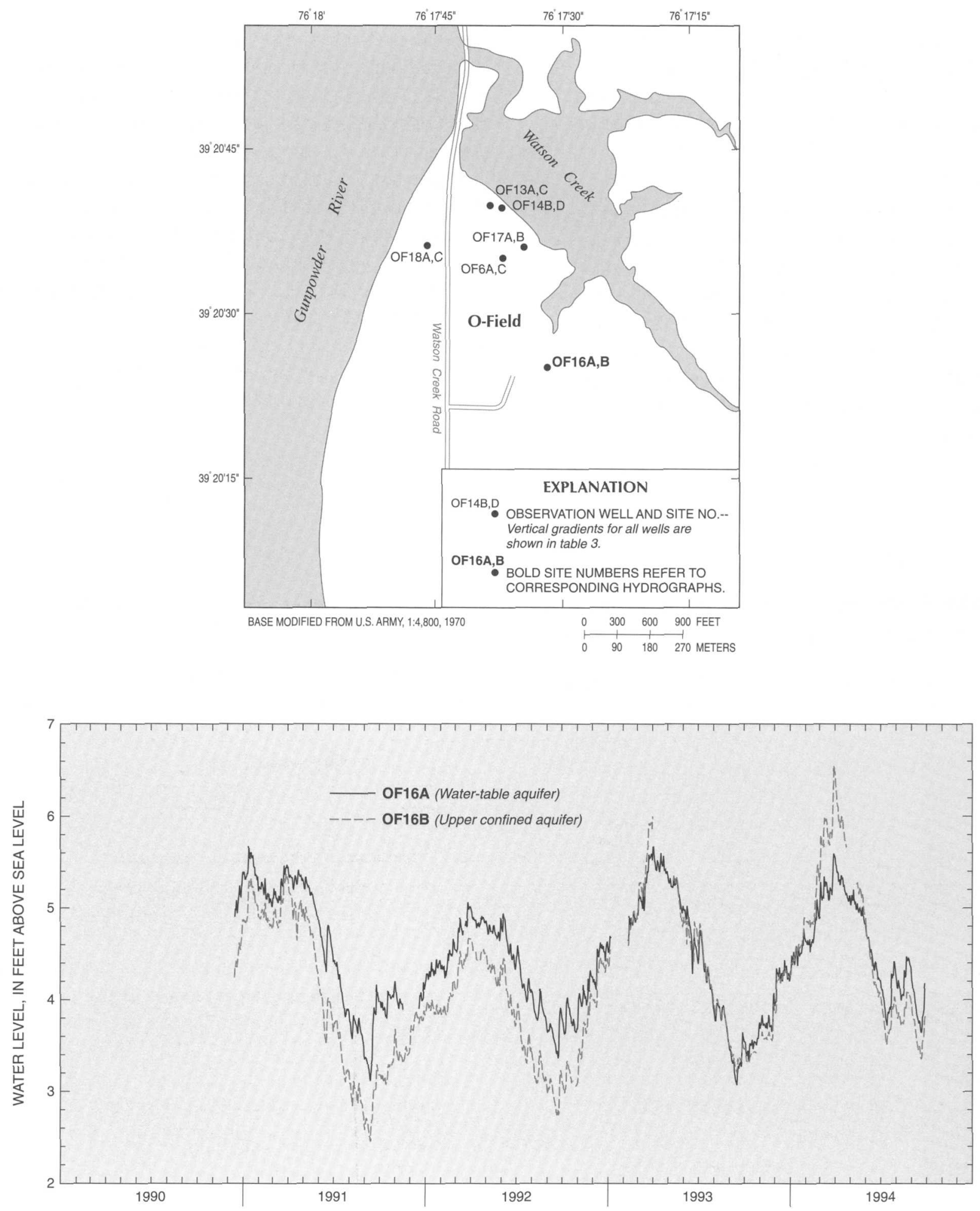

Figure 8. Selected wells, well clusters, and hydrographs of water levels in the O-Field area, Aberdeen Proving Ground, Maryland. 
Hydrographs of water levels in Nemoff and Vroblesky (1989, figs. 6, 9, 10,13, and 15) show that a seasonal variation in the hydraulic head exists in the lower confined aquifer, indicating some hydraulic connection with surficial recharge.

The seasonal patterns of hydraulic head rise and fall in the O-Field area throughout the period of record for the well pairs are similar to the patterns seen in the wells at Graces Quarters and Canal Creek. As in the other areas discussed, flow in the water-table aquifer at the O-Field area is influenced by the presence of surface-water bodies and by seasonal recharge variations. Unlike Graces Quarters, the direction of vertical gradients at the O-Field area (table 3) changed during the period of record in five of the six well pairs analyzed. Data in Nemoff and Vroblesky (1989, table 13) indicate that potential flow downward from the water-table aquifer toward the upper and lower confined aquifers predominates during the spring, and that potential flow upward toward the water-table aquifer predominates during the summer and autumn. The lack of a consistent downward gradient indicates that discharge from the aquifers is probably affected by evapotranspiration or other seasonal hydrologic processes. The surficial aquifer discharges locally to the Gunpowder River and Watson Creek.

Table 3. Minimum and maximum vertical hydraulic gradients in selected well clusters in the O-Field area, Aberdeen Proving Ground, Maryland

[Screen midpoint elevation in feet above or below sea level; vertical gradients in feet per foot; <, less than; --, no gradient of the specified direction was noted during the period of record; shading and white space used to delineate well pairs used to calculate vertical gradients]

\begin{tabular}{|c|c|c|c|c|c|c|c|}
\hline \multirow{3}{*}{$\begin{array}{l}\text { Well no. } \\
\text { (fig. 8) }\end{array}$} & \multirow{3}{*}{$\begin{array}{l}\text { Aquifer } \\
\text { name }\end{array}$} & \multirow{3}{*}{$\begin{array}{l}\text { Aquifer } \\
\text { type }^{1}\end{array}$} & \multirow{3}{*}{$\begin{array}{l}\text { Screen } \\
\text { midpoint } \\
\text { elevation }^{2}\end{array}$} & \multicolumn{4}{|c|}{ Vertical gradient ${ }^{3}$} \\
\hline & & & & \multicolumn{2}{|c|}{ Upward } & \multicolumn{2}{|c|}{ Downward } \\
\hline & & & & Minimum & Maximum & Minimum & Maximum \\
\hline OFGA & Water rable & Unconfined & 7.6. & 0.01 & 002 & 0.00 & 0.01 \\
\hline $\begin{array}{l}\text { OF13A } \\
\text { OF13C }\end{array}$ & $\begin{array}{l}\text { Water table } \\
\text { Upper confined }\end{array}$ & $\begin{array}{l}\text { Unconfined } \\
\text { Confined }\end{array}$ & $\begin{array}{r}-0.5 \\
-18.6\end{array}$ & $<.01$ & .02 & 4 & .03 \\
\hline OFI $14 \mathrm{~B}$ & $\begin{array}{l}\text { Water table } \\
\text { lower confined }\end{array}$ & Unconfined & . & : & 01 & & \\
\hline $\begin{array}{l}\text { OF16A } \\
\text { OF16B }\end{array}$ & $\begin{array}{l}\text { Water table } \\
\text { Upper confined }\end{array}$ & $\begin{array}{l}\text { Unconfined } \\
\text { Confined }\end{array}$ & $\begin{array}{r}-3.5 \\
-13.5\end{array}$ & -. & -- & .04 & .08 \\
\hline OFI7A & Water table & Unconfined & . 169. & $4.0 \%$ & .02 & 01 & 13 \\
\hline $\begin{array}{l}\text { OF18A } \\
\text { OF18C }\end{array}$ & $\begin{array}{l}\text { Water table } \\
\text { Lower confined }\end{array}$ & $\begin{array}{l}\text { Unconfined } \\
\text { Confined }\end{array}$ & $\begin{array}{r}-.2 \\
-73.3\end{array}$ & $<.01$ & .01 & $<.01$ & .02 \\
\hline
\end{tabular}

${ }^{1}$ Vroblesky and others (1995, p. 12-16)

2 Based on data from Nemoff and Vroblesky (1989, table 1).

${ }^{3}$ Based on data collected January 1986 through September 1987, Nemoff and Vroblesky (1989, table 13).

${ }^{4}$ Only one gradient was calculated for the specified direction during the period of record. 


\section{Carroll Island}

The shallow (less than $200 \mathrm{ft}$ below land surface) hydrogeologic system at Carroll Island includes a surficial aquifer, an upper confining unit, an upper confined aquifer, and a lower confining unit (fig. 9; Tenbus and Phillips, 1996, p. 12). The surficial aquifer ranges in thickness from 7 to $32 \mathrm{ft}$, is fairly continuous beneath Carroll Island (Tenbus and Phillips, 1996, p. 23), and is lithologically similar to the combined water-table and upper confined aquifers in the $\mathrm{O}$-Field area described by Vroblesky and others (1995, p. 11-25). The surficial aquifer is not present west of Carroll Island and is thought to pinch out near Saltpeter and Seneca Creeks (Tenbus and Phillips, 1996, p. 23). The upper confining unit appears to be continuous beneath
Carroll Island and ranges in thickness from 19 to $41 \mathrm{ft}$ (Tenbus and Phillips, 1996, p. 33). The confining unit is part of the Talbot Formation (Tenbus and Phillips, 1996, p. 13) and is lithologically similar to the confining unit beneath the upper confined aquifer at the O-Field area (Vroblesky and others, 1995, p. 25). The upper confined aquifer is continuous beneath Carroll Island, but thins and becomes discontinuous west of Seneca and Saltpeter Creeks, beneath the mainland (Tenbus and Phillips, 1996, p. 36). The upper confined aquifer is similar to the lower confined aquifer in the O-Field area described by Vroblesky and others (1995, p. 27-28). The lower confining unit, which is part of the Patapsco Formation, is present but not well defined at Carroll Island (Tenbus and Phillips, 1996, p. 41).

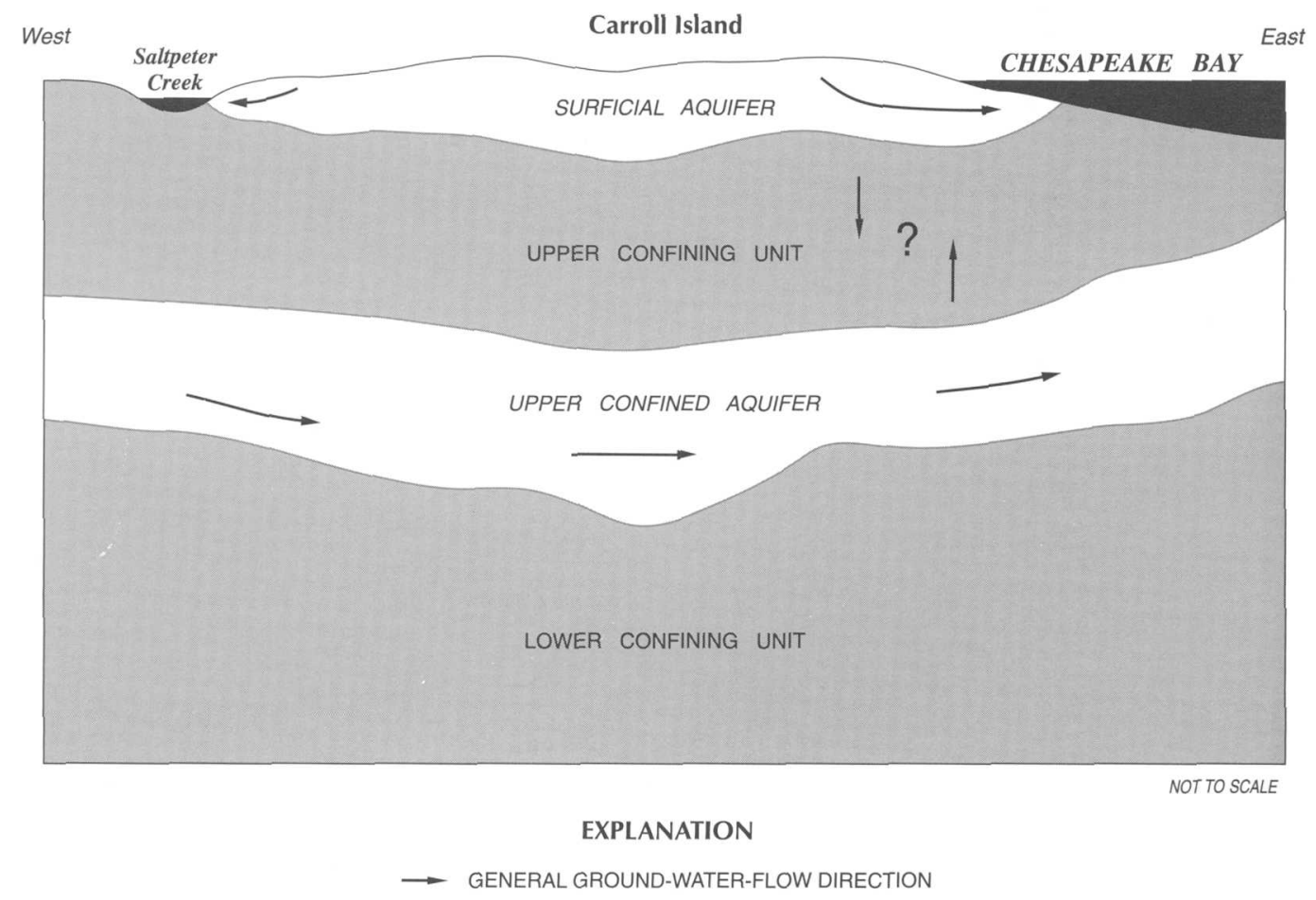

Figure 9. Hydrogeologic units and general ground-water-flow direction on Carroll Island, Aberdeen Proving Ground, Maryland. 
Water levels in the surficial aquifer are influenced by recharge (Tenbus and Phillips, 1996, p. 25). During a period of high recharge and low evapotranspiration, ground water in the surficial aquifer flowed radially from the east-central part of Carroll Island (Tenbus and Phillips, 1996, fig. 12). Declining water levels after a period of low recharge and high evapotranspiration caused gradient reversals, with water levels in some wells dropping below sea level (Tenbus and Phillips, 1996, fig. 13).

Ground-water flow in the upper confined aquifer is to the south, east, and southeast, but the horizontal gradient is low (Tenbus and Phillips, 1996, p. 36). Seasonal water withdrawal from the upper confined aquifer by an aquaculture facility located 2,000 ft west of Carroll Island affects heads in the aquifer (Tenbus and Phillips, 1996, p. 28). Heads in the upper confined aquifer are controlled by the loading effects of tidal fluctuations (Tenbus and Phillips, 1996, p. 41).

Hydrographs of water levels for two well pairs (I22B and A; I54A and B) screened in the surficial and confined aquifers on Carroll Island are shown in figure 10. Seasonal variations of recharge are more evident in wells screened in the surficial aquifer than in those screened in the confined aquifer, indicating a poor hydraulic connection between the aquifers. Well I54B (fig. 10) shows a head decline that is directly attributable to pumping at the aquaculture facility in August 1988 (Tenbus and Phillips, 1996, p. 28) and a similar head drop in the summer of 1989 (fig. 10). Hydrographs of wells screened in the confined aquifer show rapid, short-term water-level fluctuations in response to tidal changes in the surrounding estuaries. The instantaneous response of head in the confined aquifer supports other evidence that the overlying confining unit is continuous. The tidal-loading patterns evident in all of the Carroll Island hydrographs are similar to those seen in the confined aquifers at the other study areas.

Vertical gradients at Carroll Island (table 4) changed direction at least once during the period of record in each of the six well pairs analyzed. Water-level data (Ham, Sears, and others, 1991, table 7) indicate that potential flow downward from the surficial aquifer toward the upper confined aquifer predominates in the winter, and that potential flow upward toward the surficial aquifer pre-dominates in the drier summer months. This seasonal response is similar to that noted in the O-Field area. The minimum and maximum gradients are similar and within an order of magnitude of each other. Data indicate the upper confining unit beneath Carroll Island is continuous, so that significant flow probably is not occurring between the surficial and confined aquifer.

\section{J-Field Area}

The hydrogeologic units in the J-Field area include a surficial aquifer, a confining unit, and a confined aquifer that are part of the Talbot Formation (fig. 11; Hughes, 1993, p. 1), and the confining units and confined aquifers of the Patapsco Formation (Hughes, 1993, p. 28, 29). The surficial aquifer, a mixture of interbedded sand and clay, ranges in thickness from approximately 25 to $40 \mathrm{ft}$ and is present throughout the J-Field area. The aquifer is lithologically similar to, but somewhat thicker than, the surficial aquifer at Carroll Island and the combined watertable and upper confined aquifers in the O-Field area. Ground-water flow in the surficial aquifer is generally toward topographically low areas--the Gunpowder River, Chesapeake Bay, and marsh areas (Hughes, 1993, p. 29). The confining unit, a silty, sandy clay mixture, increases in thickness from $40 \mathrm{ft}$ in the western part of the study area to $107 \mathrm{ft}$ in the eastern part. It pinches out toward the southern and northern boundaries of a paleochannel (Hughes, 1993, p. 28; Hughes, 1995, p. 7).

Beneath the confining unit is a confined aquifer, composed primarily of gravelly sand, clay, and clayey sand, that ranges in thickness from $50 \mathrm{ft}$ in the western part of the study area to approximately $15 \mathrm{ft}$ in the southeast (Hughes, 1993, p. 28; Hughes, 1995, p. 7). As with the confining unit above, the paleochannel marks the boundary of the confined aquifer. The Patapsco 

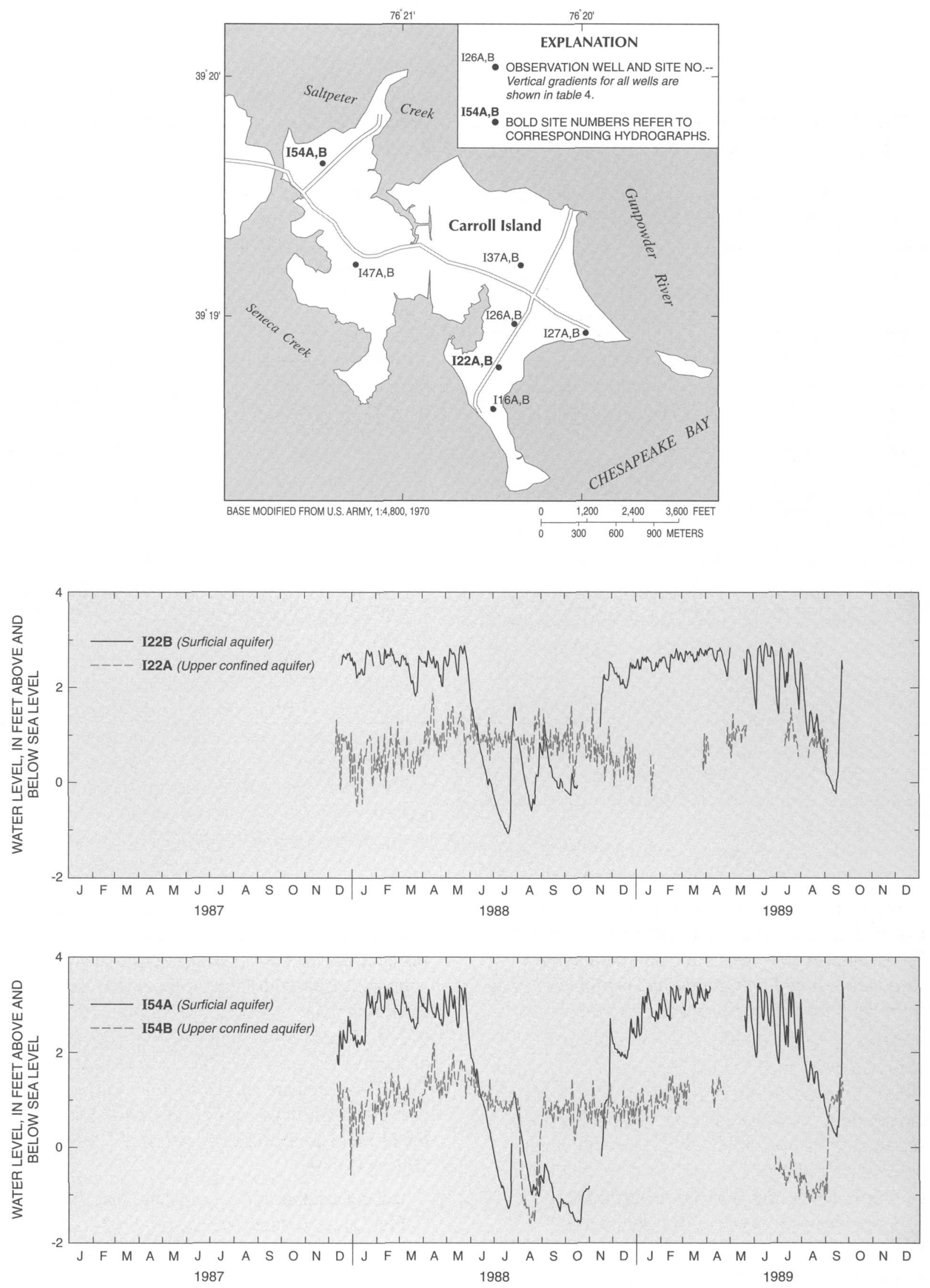

Figure 10. Selected wells, well clusters, and hydrographs of water levels on Carroll Island, Aberdeen Proving Ground, Maryland. 
Table 4. Minimum and maximum vertical hydraulic gradients in selected well clusters on Carroll Island, Aberdeen Proving Ground, Maryland

[Screen midpoint elevation in feet above or below sea level; vertical gradients in feet per foot; <, less than; shading and white space used to delineate well pairs used to calculate vertical gradients; --, no gradient]

\begin{tabular}{|c|c|c|c|c|c|c|c|c|}
\hline \multirow{3}{*}{$\begin{array}{l}\text { Well no. } \\
\text { (fig. 9) }\end{array}$} & \multirow{3}{*}{$\begin{array}{l}\text { Aquifer } \\
\text { name }{ }^{1}\end{array}$} & \multirow{3}{*}{$\begin{array}{l}\text { Aquifer } \\
\text { type }^{2}\end{array}$} & \multirow{3}{*}{$\begin{array}{l}\text { Screen } \\
\text { midpoint } \\
\text { elevation }\end{array}$} & \multicolumn{4}{|c|}{ Vertical gradient ${ }^{4}$} & \multirow[b]{3}{*}{$\begin{array}{l}\text { Period of } \\
\text { record }\end{array}$} \\
\hline & & & & \multicolumn{2}{|c|}{ Upward } & \multicolumn{2}{|c|}{ Downward } & \\
\hline & & & & Minimum & Maximum & Minimum & Maximum & \\
\hline $116 \mathrm{~B}$ & Surficial & $\begin{array}{l}\text { Unconfined } \\
\text { Confined: }\end{array}$ & $\begin{array}{l}-4.5 \\
-4.0\end{array}$ & 0.02 & $=0.05$ & 0.01 & 0.07 & Oct 1987 Dec. 1988 \\
\hline $\begin{array}{l}122 \mathrm{~B} \\
122 \mathrm{~A}\end{array}$ & $\begin{array}{l}\text { Surficial } \\
\text { Confined }\end{array}$ & $\begin{array}{l}\text { Semiconfined } \\
\text { Confined }\end{array}$ & $\begin{array}{l}-12.5 \\
-56.0\end{array}$ & .02 & .04 & .02 & .06 & Nov. 1987-Dec. 1988 \\
\hline$\frac{126 \mathrm{~B}}{126 \mathrm{~A}}$ & $\begin{array}{l}\text { Surficial } \\
\text { Surficial }\end{array}$ & $\begin{array}{l}\text { Unconfined: } \\
\text { Sermiconfined }\end{array}$ & $\begin{array}{l}-5.5 \\
-21.5\end{array}$ & $<01$ & 05 & \%. 01 & 10 & Nov. 1987 Dec 1988 \\
\hline $\begin{array}{l}127 \mathrm{~B} \\
127 \mathrm{~A}\end{array}$ & $\begin{array}{l}\text { Surficial } \\
\text { Confined }\end{array}$ & $\begin{array}{l}\text { Unconfined } \\
\text { Confined }\end{array}$ & $\begin{array}{r}-1.5 \\
-54.0\end{array}$ & .01 & .04 & .02 & .07 & Dec. 1987-Dec. 1988 \\
\hline $\begin{array}{l}137 \mathrm{~B} \\
137 \mathrm{~A}\end{array}$ & Suricial: & $\begin{array}{l}\text { Semiconfined } \\
\text { Confined: }\end{array}$ & $\begin{array}{l}1115 \\
-245\end{array}$ & $<.01$ & 09 & & 01 & Nov $1987 \cdot \mathrm{Dec} \cdot 1988$ \\
\hline $\begin{array}{l}147 \mathrm{~A} \\
147 \mathrm{~B}\end{array}$ & $\begin{array}{l}\text { Surficial } \\
\text { Confined }\end{array}$ & $\begin{array}{l}\text { Unconfined } \\
\text { Confined }\end{array}$ & $\begin{array}{r}-4.5 \\
-59.4\end{array}$ & $<.01$ & .03 & .02 & .05 & Nov. 1987-Dec. 1988 \\
\hline $\begin{array}{l}154 A \\
154 B\end{array}$ & $\begin{array}{l}\text { Surficial } \\
\text { Confined }\end{array}$ & $\begin{array}{l}\text { Unconfined: } \\
\text { Confined: }\end{array}$ & $\begin{array}{l}-2.5 \\
-50.0\end{array}$ & 2.01 & 05 & 01. & .04 & Nov. 1987. Dec 1988 \\
\hline
\end{tabular}

Formation acts as a lower confining unit due to the low hydraulic conductivities (Hughes, 1995, table 7). Ground-water flow in the confined aquifer responds to tidal fluctuations, and is probably away from the J-Field area toward the estuaries.

Hydrographs of water levels for one well pair screened in the surficial and confined aquifers in the $\mathrm{J}$-Field area are shown in figure 12. As with all of the aquifers investigated in the other study areas, seasonal variations of recharge cause the higher hydraulic heads that are evident in the surficial aquifer in the spring, and the lower heads in the typically drier summer and autumn months. Hydrographs of wells screened in the confined aquifer (Phelan and others, 1996, fig. 8) show subdued seasonal variation and rapid, short-term water-level fluctuations in response to tidal changes in the surrounding estuaries. The instantaneous response of the confined aquifer supports other evidence that the overlying confining unit is continuous (Hughes, 1993, p. 36). The tidal-loading patterns evident in all of the hydrographs from the confined aquifer in the J-Field area are similar to those patterns seen in the well-confined aquifers at Carroll Island and the O-Field area, and parts of Canal Creek and Graces Quarters.

Like gradients at Carroll Island and the $\mathrm{O}$-Field area, vertical gradients in the J-Field area (table 5) changed direction at least once during the period of record in each of the four well pairs analyzed. Water-level data (Phelan and others, 


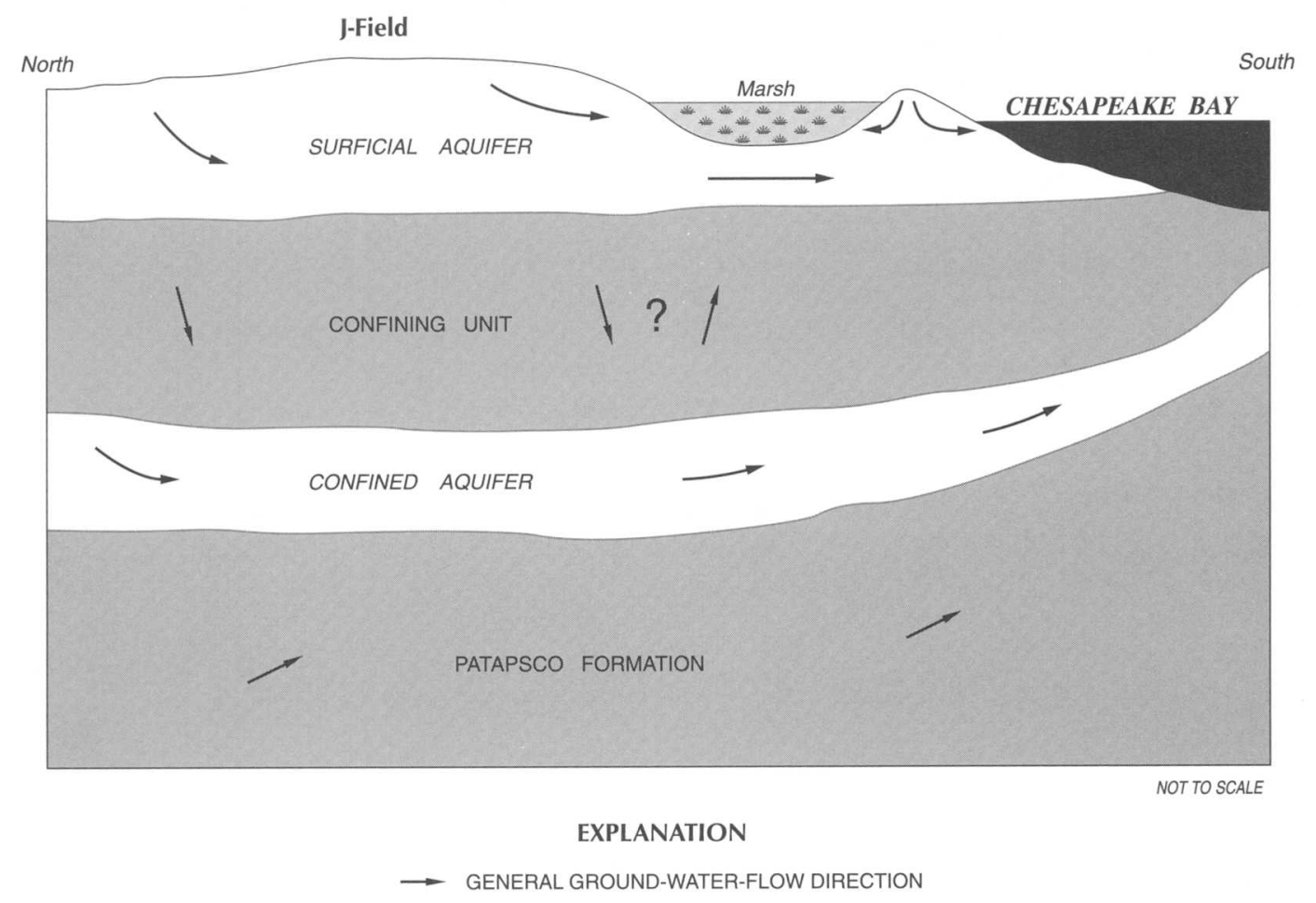

Figure 11. Hydrogeologic units and general ground-water-flow direction in the J-Field area, Aberdeen Proving Ground, Maryland.

1996 , table 8) indicate that potential flow downward from the surficial aquifer toward the upper confined aquifer predominates in the spring, and that potential flow upward toward the surficial aquifer predominates in the drier summer months. The seasonally controlled minimum and maximum head gradients are balanced within an order of magnitude of each other. Data from Hughes, 1993 (p. 36) indicate that the overlying confining unit is continuous, therefore, significant flow probably is not occurring between the surficial and confined aquifer in the Talbot Formation. 

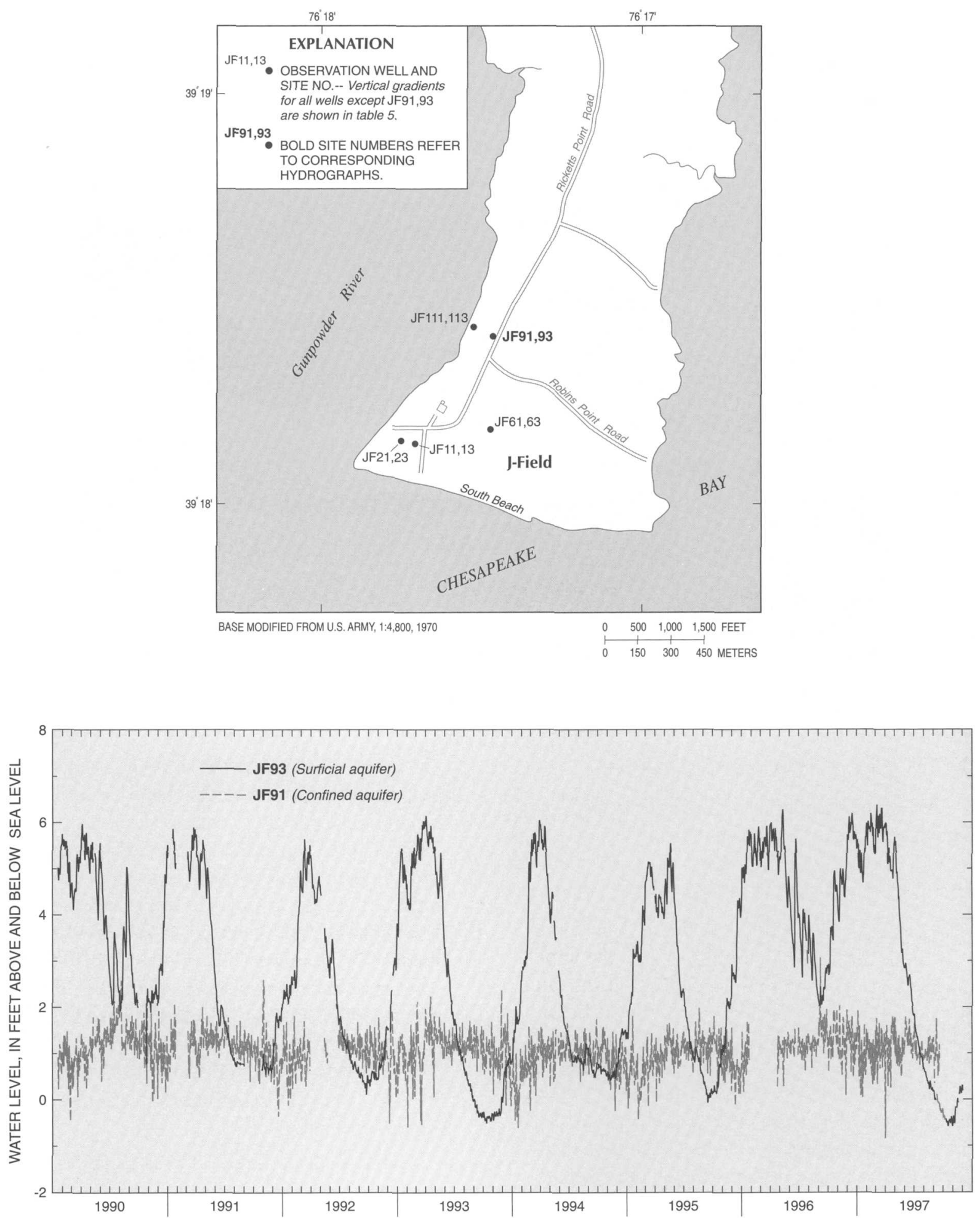

Figure 12. Selected wells, well clusters, and hydrographs of water levels in the J-Field area, Aberdeen Proving Ground, Maryland. 
Table 5. Minimum and maximum vertical hydraulic gradients in selected well clusters in the $J$-Field area, Aberdeen Proving Ground, Maryland

[Screen midpoint elevation in feet above or below sea level; vertical gradients in feet per foot; <, less than; shading and white space used to delineate well pairs used to calculate vertical gradients]

\begin{tabular}{|c|c|c|c|c|c|c|c|c|}
\hline \multirow[b]{3}{*}{$\begin{array}{l}\text { Well no. } \\
\text { (fig. 12) }\end{array}$} & \multirow[b]{3}{*}{$\begin{array}{l}\text { Aquifer } \\
\text { name } 1\end{array}$} & \multirow[b]{3}{*}{$\begin{array}{l}\text { Aquifer } \\
\text { type } 2\end{array}$} & \multirow{3}{*}{$\begin{array}{l}\text { Screen } \\
\text { midpoint } \\
\text { elevation } 3\end{array}$} & \multicolumn{4}{|c|}{ Vertical gradient ${ }^{4}$} & \multirow[b]{3}{*}{$\begin{array}{l}\text { Period of } \\
\text { record }\end{array}$} \\
\hline & & & & \multicolumn{2}{|c|}{ Upward } & \multicolumn{2}{|c|}{ Downward } & \\
\hline & & & & Minimum & Maximum & Minimum & Maximum & \\
\hline 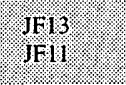 & $\begin{array}{l}\text { Surficial } \\
\text { Gonfined: }\end{array}$ & $\begin{array}{l}\text { Unconfined: } \\
\text { Confined }\end{array}$ & $\frac{15}{15.5}$ & 00.01 & 0.02 & $<0.01$ & 0.06 & Nov. 1989-Aug 1994 \\
\hline $\begin{array}{l}\mathrm{JF} 23 \\
\mathrm{JF} 21\end{array}$ & $\begin{array}{l}\text { Surficial } \\
\text { Confined }\end{array}$ & $\begin{array}{l}\text { Unconfined } \\
\text { Confined }\end{array}$ & $\begin{array}{l}-14.5 \\
-66.5\end{array}$ & $<.01$ & .02 & $<.01$ & .05 & Nov. 1989-Aug. 1994 \\
\hline IF 63 & $\begin{array}{l}\text { Surficial } \\
\text { Confined }\end{array}$ & $\begin{array}{l}\text { Unconfined } \\
\text { Confined: }\end{array}$ & $\begin{array}{r}13.5 \\
-935\end{array}$ & 801 & .02 & 201 & & Nov. 1989-Aug. 1994 \\
\hline $\begin{array}{l}\text { JF113 } \\
\text { JF111 }\end{array}$ & $\begin{array}{l}\text { Surficial } \\
\text { Confined }\end{array}$ & $\begin{array}{l}\text { Unconfined } \\
\text { Confined }\end{array}$ & $\begin{array}{l}-16.5 \\
-65.0\end{array}$ & $<.01$ & .02 & $<.01$ & .04 & Nov. 1989-Jul. 1994 \\
\hline
\end{tabular}

${ }^{1}$ From Phelan and others (1996, table 1).

2 Based on screen depths and lithologic information from Hughes (1993, tables 6 and 8).

${ }^{3}$ Based on data from Hughes (1993, table 6).

${ }^{4}$ Based on data from Phelan and others $(1996$, table 8$)$.

\section{SUMMARY AND CONCLUSIONS}

Environmental studies conducted in the Edgewood Area of Aberdeen Proving Ground since the mid-1980's by the U.S. Geological Survey have generated large amounts of information about ground water at the Canal Creek area, Graces Quarters, the O-Field area, Carroll Island, and the J-Field area. A comparison of hydrologic data and interpretations from these studies has been used to determine similarities and differences between the aquifers.

The study areas are located on unconsolidated sand, silt, and clay deposits in the Atlantic Coastal Plain. Because the deposits that comprise the shallow aquifers are discontinuous, the shallow ground-water-flow systems are local rather than extensive across the Edgewood Area.

Ground-water flow within and among the three aquifers of the Canal Creek area (surficial, Canal Creek, and lower confined aquifer) is influenced by a number of factors. Seasonal differences in recharge affect hydraulic head in the three aquifers.
This results in about a 3-ft seasonal variation in hydraulic head in the surficial aquifer and a $1-\mathrm{ft}$ variation in hydraulic head in parts of the Canal Creek aquifer and in the lower confined aquifer. Upward hydraulic gradients between the surficial and Canal Creek aquifers at some well pairs and downward hydraulic gradients at others indicate that the two aquifers receive recharge from each other in different locations. Hydraulic gradients between the Canal Creek and lower confined aquifers were upward, although very slight in some locations. Ground-water discharge occurs locally, especially to surface-water bodies, in the Canal Creek area.

Ground-water flow at Graces Quarters occurs among an unconfined surficial aquifer, a semiconfined middle aquifer, and a confined lower aquifer. Hydrographs of water levels and downward vertical gradients indicate that the surficial and middle aquifers are hydraulically connected and obtain seasonal recharge predominantly from precipitation. Upward 
hydraulic gradients near the estuaries in the summer of 1997 demonstrate that the middle aquifer discharges to the surficial aquifer, and to the surrounding estuaries. Vertical gradients, the presence of a 100 -ft-thick clay confining unit, and the effects of offsite pumping provide evidence that the lower aquifer is not hydraulically connected with the surficial or middle aquifers.

The three aquifers in the O-Field area include a water-table aquifer, an upper confined aquifer, and a lower confined aquifer. Hydrographs of water levels indicate that the hydraulic head varies seasonally in the water-table and upper confined aquifers. The hydrographs, vertical gradient data, and information from previous reports indicate that gradients between the water-table and upper confined aquifers can change on a seasonal basis. The lack of a consistent downward gradient indicates that discharge from the aquifers is probably affected by evapotranspiration or other seasonal hydrologic processes. Ground-water discharge from the surficial aquifer is to the Gunpowder River and Watson Creek near those estuaries.

The two aquifers on Carroll Island include a surficial and an upper confined aquifer. The surficial aquifer is similar to the combined watertable and upper confined aquifers in the O-Field area, and the upper confined aquifer is similar to the lower confined aquifer at O-Field. Water levels in the surficial aquifer exhibit seasonal variation, and low recharge coupled with high evapotranspiration rates can cause the hydraulic head to fall below sea level. Head in the upper confined aquifer is influenced by tides in the estuaries. On the western part of the island, the head in the upper confined aquifer responds to seasonal pumping from a nearby aquaculture facility. The upper confining unit beneath Carroll Island is continuous and there is a small horizontal hydraulic gradient in the confined aquifer.

In the J-Field area, the surficial aquifer is similar to, but thicker than, the surficial aquifer at Carroll Island and the combined water-table and upper confined aquifers in the O-Field area. A confining unit and confined aquifer are beneath the surficial aquifer. Similar to Carroll Island, the hydraulic head in the surficial aquifer in the $\mathrm{J}$-Field area varies seasonally in response to recharge, and the gradient between the surficial and confined aquifers changes direction. Patterns in the hydrographs from the confined aquifer in the Talbot Formation in the J-Field area are similar to those patterns seen in the confined aquifers at the other study areas.

Upward hydraulic gradients and seasonal reversals of vertical hydraulic gradients between aquifers indicate the potential for local groundwater discharge from most of the aquifers that were studied in the Edgewood Area, especially to the surrounding estuaries. Hydraulic head in most of the confined aquifers responded to tidal loading effects from nearby estuaries. The shallow ground-water-flow systems are local rather than extensive across the Edgewood Area. 
Banks, W.S.L., Smith, B.S., and Donnelly, C.A., 1996, Hydrogeologic setting, hydraulic properties, and ground-water flow at the O-Field area of Aberdeen Proving Ground, Maryland: U.S. Geological Survey Water-Resources Investigations Report 95-4248, 29 p.

Ham, L.K., Sears, L.N., Phillips, S.W., and Tenbus, F.J., 1991, Hydrogeologic data for Carroll Island, Aberdeen Proving Ground, Maryland: U.S. Geological Survey Open-File Report 89-388, $105 \mathrm{p}$.

Ham, L.K., Tenbus, F.J., Sears, L.N., and Phillips, S.W., 1991, Hydrogeologic data for Graces Quarters, Aberdeen Proving Ground, Maryland: U.S. Geological Survey Open-File Report 91-71, $68 \mathrm{p}$.

Hughes, W. B., 1993, Hydrogeology and soil gas at J-Field, Aberdeen Proving Ground, Maryland: U.S. Geological Survey Water-Resources Investigations Report 93-4087, 83 p. 1995, Ground-water flow and the possible effects of remedial actions at J-Field, Aberdeen Proving Ground, Maryland: U.S. Geological Survey Water-Resources Investigations Report 95-4075, $39 \mathrm{p}$.

Lorah, M.M., and Clark, J.S., 1996, Contamination of ground water, surface water, and soil, and evaluation of selected ground-water pumping alternatives in the Canal Creek area of Aberdeen Proving Ground, Maryland: U.S. Geological Survey Open-File Report 95-282, 318 p.

Lorah, M.M., Olsen, L.D., Smith, B.L., Johnson, M.A., and Fleck, W.B., 1997, Natural attenuation of chlorinated volatile organic compounds in a freshwater tidal wetland, Aberdeen Proving Ground, Maryland: U.S. Geological Survey Water-Resources Investigations Report 97-4171, 95 p.

Nemoff, P.R., and Vroblesky, D.A., 1989, Hydrogeologic and chemical data for the O-Field area, Aberdeen Proving Ground, Maryland: U.S. Geological Survey Open-File Report 89-238, 70 p.

Oliveros, J.P., and Gernhardt, Patrice, 1989, Hydrogeologic data for the Canal Creek area, Aberdeen Proving Ground, Maryland: U.S. Geological Survey Open-File Report 89-387, $71 \mathrm{p}$.
Oliveros, J.P., and Vroblesky, D.A., 1989, Hydrogeology of the Canal Creek area, Aberdeen Proving Ground, Maryland: U.S. Geological Survey Water-Resources Investigations Report 89-4021, 50 p.

Owens, J.P., 1969, Coastal Plain rocks of Harford County, in The geology of Harford County, Maryland: Maryland Geological Survey, p. 77-103.

Phelan, D.J., Marchand, E.H., Cashel, M.L., Koterba, M.T., Olsen, L.D., and Nemoff, P.R., 1996, Hydrogeologic, soil, and water-quality data for J-Field, Aberdeen Proving Ground, Maryland: U.S. Geological Survey Open-File Report 96-128, 191 p.

Tenbus, F.J., and Blomquist, J.D., 1995, Hydrogeology and water quality in the Graces Quarters area of Aberdeen Proving Ground, Maryland: U.S. Geological Survey WaterResources Investigations Report 94-4175, $115 \mathrm{p}$.

Tenbus, F.J., and Fleck, W.B., 1996, Groundwater flow and the potential effects of remediation at Graces Quarters, Aberdeen Proving Ground, Maryland: U.S. Geological Survey Water-Resources Investigations Report 96-4044, 31 p.

Tenbus, F.J., and Phillips, S.W., 1996, Hydrogeology and chemical quality of water and soil at Carroll Island, Aberdeen Proving Ground, Maryland: U.S. Geological Survey Water-Resources Investigations Report 96-4169, $156 \mathrm{p}$.

Vroblesky, D.A., and Fleck, W.B., 1991, Hydrogeologic framework of the Coastal Plain of Maryland, Delaware, and the District of Columbia: U.S. Geological Survey Professional Paper 1404-E, 45 p.

Vroblesky, D.A., Lorah, M.M., and Oliveros, J.P., 1995, Ground-water, surface-water, and bottom-sediment contamination in the O-Field area, Aberdeen Proving Ground, Maryland, and possible effects of selected remedial actions on ground water: U.S. Geological Survey Water-Supply Paper 2399, $95 \mathrm{p}$. 


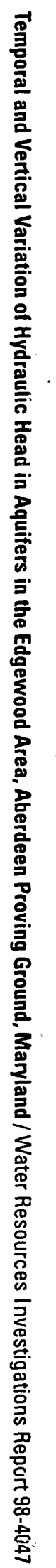

